\title{
Seasonality of recruitment in Antarctic sessile marine benthos
}

\author{
David A. Bowden* \\ Natural Environment Research Council, British Antarctic Survey, High Cross, Madingley Road, Cambridge CB3 0ET, UK
}

\begin{abstract}
Recruitment is a principal factor determining the establishment, diversity and persistence of assemblages in marine benthic ecosystems. Despite considerable research in temperate and tropical latitudes, however, almost nothing is known of recruitment processes in polar regions. This study presents the first assessment of short-term recruitment of sessile epibenthos at a location within the Antarctic Circle $\left(66.5^{\circ} \mathrm{S}\right)$. Recruitment was measured using acrylic panels immersed at 2 depths (8 and $20 \mathrm{~m}$ ) at each of 3 locations in Ryder Bay, SW Antarctic Peninsula (67 35' S, 68 ${ }^{\circ} 10^{\prime} \mathrm{W}$ ). Recruitment to upward- and downward-facing panel surfaces was monitored at monthly intervals from March to August 2001, and from April 2002 to February 2003. A total of 41 taxa from 9 phyla were recorded. Bryozoans and spirorbid polychaetes were the most abundant groups, and cheilostome bryozoans were the most speciose. Recruitment occurred throughout the year and average assemblage composition followed a cyclical pattern, suggesting annual reproduction in a majority of the taxa recorded. Within this pattern, most species exhibited pronounced seasonality. In contrast to the general pattern of summer recruitment in temperate assemblages, however, a peak in the number of taxa recruiting occurred in late winter and for cheilostome bryozoans the timing of recruitment showed a correlation with competitive ability: weaker competitors recruiting earlier in the year than stronger competitors. It is suggested that the apparent trend for winter recruitment may be an adaptive response to an environment in which disturbance peaks during summer. Total recruitment to upward-facing surfaces during the study was comparable with that to downward-facing surfaces but seasonal reductions in the relative number of recruits on upper surfaces suggest that post-settlement mortality may be important.
\end{abstract}

KEY WORDS: Recruitment · Seasonality · Polar · Settlement · Mortality $\cdot$ Sessile $\cdot$ Disturbance · Marine benthos

Resale or republication not permitted without written consent of the publisher

\section{INTRODUCTION}

Accurate data on the timing, abundance and diversity of recruitment are central to understanding the dynamics of benthic ecosystems (Connell 1985, Underwood \& Fairweather 1989, Gaines \& Bertness 1992, Caley et al. 1996, Connolly \& Roughgarden 1999, Connolly et al. 2001, Gimenez 2004). Consequently, in temperate and tropical regions there has been considerable research on patterns of recruitment, much of this work concentrating on individual species or assemblages in the rocky intertidal (e.g. Connell 1985, Menge 1991, Gaines \& Bertness 1993, Underwood \& Anderson 1994, Booth \& Brosnan 1995, Menge 2000).
In higher latitudes, the deep sea, and in sublittoral environments in general, by contrast, there are few published studies of recruitment. For the validation of any general model of benthic community dynamics, however, there is a need for data from assemblages across a broad range of environments and Todd (1998) stressed the requirement for investigation of whole assemblages, rather than single species, in assessing the relative importance of pre- and post-settlement processes.

In Antarctic nearshore waters, the combination of extremely low, relatively constant, seawater temperatures, a naturally occurring gradient of decreasing icemediated disturbance with depth, highly seasonal pri- 
mary production, and biogeographic isolation over some 25 million yr, has created an environment in which rates of growth, reproduction and colonization among native taxa are apparently very slow (Pearse et al. 1991b, Arntz et al. 1994, but see also Barnes \& Arnold 2001b), yet disturbance is frequent. Despite this, nearshore marine benthic assemblages in the Antarctic are diverse and support high standing stocks (Brey \& Clarke 1993, Arntz et al. 1994, Clarke \& Johnston 2003). The region, therefore, presents opportunities for studying the life-history adaptations by which slow-growing benthic species are able to persist in habitats with highly seasonal food input and frequent natural disturbance. To date, however, very few studies of benthic recruitment have been conducted in the Antarctic and published data are sparse.

Dayton (1989) deployed extensive settlement panel arrays over a $10 \mathrm{yr}$ period at McMurdo Sound ( $77^{\circ} 50^{\prime} \mathrm{S}$, $166^{\circ} 40^{\prime} \mathrm{E}$ ) but published no data from this study other than an observation that, at 1 site, there was no colonization of panels after 5 yr but heavy colonization by a diverse assemblage after 10. Also at McMurdo, Pearse \& Pearse (1991) immersed small glass slides and published a brief, qualitative report describing a sparse assemblage dominated by bryozoans at the end of 1 yr. At King George Island (62 $\left.12^{\prime} \mathrm{S}, 57^{\circ} 54^{\prime} \mathrm{W}\right)$ Rauschert (1991) reported heavy growth of ascidians on 3 panels recovered after 3 yr of immersion, but the main part of this experiment was lost. In the most detailed study to date, Stanwell-Smith \& Barnes (1997) at Signy Island in the South Sandwich Islands $\left(60^{\circ} 43^{\prime} \mathrm{S}\right.$, $\left.45^{\circ} 36^{\prime} \mathrm{W}\right)$, identified continuous low levels of recruitment at bi-monthly intervals throughout an annual cycle. The latter study (Stanwell-Smith \& Barnes 1997) is the only one with quantitative seasonal information, but the data are limited in both spatial and taxonomic resolution by comparison with many temperate and tropical studies and are from an arguably atypical location in the maritime Antarctic.

In this context, the principal objective of the present study was to generate high-resolution data on the seasonality, diversity and abundance of early recruitment in hard-substratum sessile assemblages at a more characteristic Antarctic location. More specifically, characteristics of the environment and the distributions of assemblages on natural substrata suggested 3 hypotheses. Firstly, in light of the brief and highly seasonal phytoplankton bloom characteristic of these latitudes (Clarke \& Leakey 1996), it was hypothesised that recruitment of the majority of sessile taxa would coincide with the period of maximum food availability during the summer months (December to February). Therefore, the project aimed to identify taxon-dependent differences in the recruitment period. Secondly, nearshore benthic assemblages in the Antarctic are characterised by conspicuous zonation with depth, which is thought to be largely attributable to the decreasing frequency of ice scour with increasing depth (Barnes 1999, Gutt 2001). Assemblages at depths shallower than $\sim 10$ to $15 \mathrm{~m}$ are generally less diverse and substrata are less heavily colonised than those at depths below $\sim 15 \mathrm{~m}$. It was, therefore, hypothesised that the taxonomic diversity of recruitment would be reduced at shallower depths. Thirdly, Stanwell-Smith \& Barnes (1997) monitored recruitment only to the lower surfaces of settlement plates, having previously observed that the undersurfaces of rocks were colonised more extensively by sessile fauna than were upper surfaces. Observation of natural substrata in these regions, however, indicates that many sessile taxa do persist and grow on exposed, upward-facing surfaces (e.g. solitary ascidians, brachiopods, sponges, octocorals), indicating that these species, at least, must recruit to upper surfaces. By simultaneously monitoring recruitment to both upper and lower surfaces of artificial plates, it was possible to address the hypothesis that recruitment is greater to downward-facing than to upward-facing surfaces.

In recruitment studies, all larvae and propagules arriving at the experimental substratum would ideally be counted ('settlement' sensu Keough \& Downes 1982, Connell 1985). In practice, however, it is generally possible to count only those surviving after the realised sampling interval. Therefore, data from most settlement plate studies incorporate some element of postsettlement mortality. Here, I use the term 'recruitment' to refer to the number of settlers surviving after an immersion period of approximately $1 \mathrm{mo}$.

\section{MATERIALS AND METHODS}

Site description. The study was conducted at 3 locations: Hangar Cove (A), South Cove (B), and Anchorage Island (C) (Fig. 1), close to the British Antarctic Survey research station at Rothera Point, Adelaide Island, West Antarctic Peninsula $\left(67^{\circ} 34.5^{\prime} \mathrm{S}, 68^{\circ} 07.0^{\prime} \mathrm{W}\right)$. Substrata at South Cove and Anchorage Island consist primarily of natural bedrock and rubble with varying amounts of fine biogenic and mineral debris depending on seabed topography. These 2 locations differ primarily in aspect and slope: South Cove is south-facing whereas Anchorage is north-facing, and South Cove has an incline of about $30^{\circ}$ from the horizontal whereas Anchorage has a much steeper, irregular drop-off. Benthic assemblages at these 2 locations are assumed to have been established over decades, if not centuries, subject only to disturbance from ice impact. Hangar Cove contrasts with the other locations in that the hard substrata here are the boulder foundations for the 
Rothera airstrip, which was constructed in 1991. The boulders are of natural rock quarried from Rothera Point and the runway extends northwards, separating Hangar Cove from the rest of North Cove. The natural substratum in Hangar Cove is a gently sloping gradient of compacted rubble covered with fine sediment.

Nearshore waters in the study area are characterized by relatively constant low temperatures (maximum annual range at $15 \mathrm{~m},-1.9$ to $+1.0^{\circ} \mathrm{C}$ ), a brief but intense summer phytoplankton bloom, and varying durations of winter sea-ice cover. Salinity is consistently high ( $\sim 33.5 \mathrm{PSU})$ at depths below $\sim 10 \mathrm{~m}$ but the upper layers of the water column can be influenced by melt water in summer. Brockington \& Clarke (2001) give a more detailed description of conditions in Ryder Bay.

Benthic assemblages at each of the study locations are described in detail by Bowden (2005), and at South Cove only by Barnes \& Brockington (2003). There is conspicuous zonation of faunal assemblages with depth, as has been described elsewhere in the Antarctic (Kirkwood \& Burton 1988, Barnes 1995). Depths

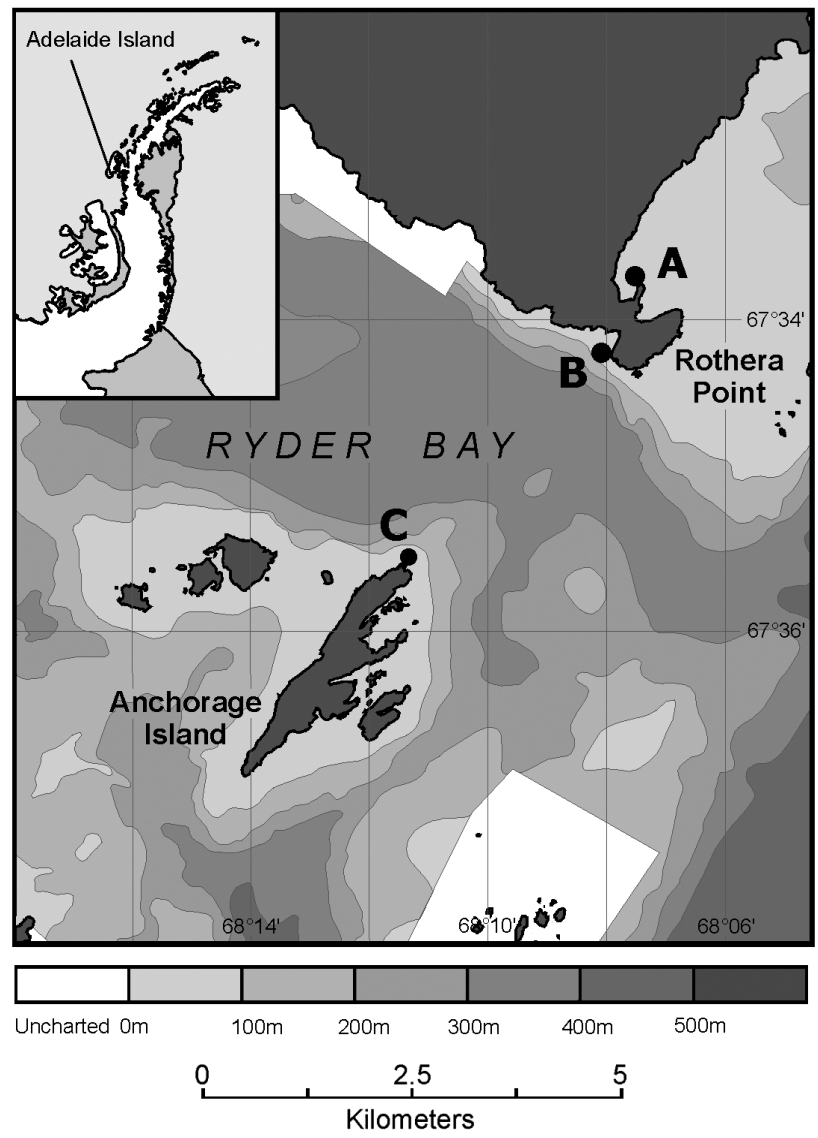

Fig. 1. The Antarctic Peninsula and Adelaide Island, with detail of Ryder Bay showing the 3 recruitment study locations. A: Hangar Cove; B: South Cove; C: Anchorage shallower than $\sim 12$ to $15 \mathrm{~m}$ are characterised by bare substratum, encrusting coralline algae, cryptic bryozoans, spirorbid polychaetes, and high densities of the urchin Sterechinus neumayeri and the limpet Nacella concinna. With increasing depth, assemblages become taxonomically richer and substrata are dominated by a variety of sessile and vagile suspension and deposit feeding fauna. Macroalgal cover is sparse and patchily distributed.

Plate units and sampling procedures. Settlement plates $(25 \times 15 \times 0.5 \mathrm{~cm})$ were constructed from opaque black acrylic sheet (Turner \& Todd 1993, Todd \& Keough 1994). Plate surfaces were machine-sanded with 60 grit abrasive to produce a coarse-textured surface, and registration marks delineating a central analysis area $(15 \times 10 \mathrm{~cm})$ were formed by $0.15 \mathrm{~cm}$ diameter drilled holes refilled with white silicon sealant. Each plate was mounted on 4 nylon studs protruding from a clear acrylic base panel and retained in place by 2 elastic strops in such a way as to be readily released and replaced by divers. Nylon nuts on the mounting studs served as spacers to maintain a $1 \mathrm{~cm}$ gap between the settlement plate undersurface and the base panel. Each base panel was, in turn, rigidly attached by webbing straps to a $25 \mathrm{~kg}$ concrete sinker. Settlement plates were replaced at approximately $30 \mathrm{~d}$ intervals. All plate deployments and retrievals were performed by divers using SCUBA and at all times, plates were transported in purpose-built, water-tight boxes to ensure that analysis surfaces were neither touched nor exposed to air.

The presence of a biofilm has been shown to influence the selection of settlement substratum in some taxa (e.g. Todd \& Keough 1994, Harder et al. 2002). Observational tests using the DAPI fluorescence technique to visualise bacteria (Porter \& Feig 1980) indicated that an appreciable biofilm developed on plates after immersion for 3 to $4 \mathrm{~d}$ in seawater at ambient temperature. Prior to initial deployment, therefore, all plates were first washed, then conditioned in flowing, $100 \mu \mathrm{m}$ filtered, seawater for a period of not less than $7 \mathrm{~d}$. Prior to each subsequent deployment, plates were abraded to remove all recruits and shell remnants and were again conditioned in filtered seawater for not less than $7 \mathrm{~d}$. On retrieval from the seabed, plates were maintained in filtered seawater at ambient temperature before being digitally photographed and examined under low-power microscopy (10 to 40×). Examination was conducted in a shallow seawater bath and thus all recruits recorded were alive at the time of census. All recruits present within the central $150 \mathrm{~cm}^{2}$ analysis area on both upper and lower plate surfaces were recorded on enlarged (A4) negative prints from the whole-plate digital images. By printing these images as negatives, recruits showed as dark marks on 
a light ground, thus allowing identification codes and image frame numbers to be written directly to a dimensionally accurate map of the plate surface. All taxa were photographed and assigned identification codes, and a reference file of digital images was maintained for each taxon in order to ensure consistency of identifications. Cheilostome bryozoans were identified from Hayward (1995), bivalve molluscs were identified by Dr. K. Linse at the British Antarctic Survey, and other taxa were recorded as higher groupings.

Experimental design and plate deployment. Arrays of 6 settlement plate units were deployed at 2 depths (8 and $20 \mathrm{~m}$ ) at each of the 3 locations (Hangar Cove, South Cove and Anchorage Island, Fig. 1), resulting in a total of 36 units. These depths were chosen as being representative of 2 broad zones: a heavily ice-scoured zone above $\sim 10 \mathrm{~m}$, and a less frequently disturbed zone below this depth. The study is thus stratified by depth, locations encompass local variability on the scale of $\sim 5 \mathrm{~km}$, and plate units are replicated $(\mathrm{n}=6)$ within each depth $\times$ location combination. Individual units within each array were placed either on, or immediately adjacent to, hard substrata, were approximately horizontal in orientation, and positioned on ledges or against boulders in such a way as to minimise risk of dislodgement or damage by ice. At $20 \mathrm{~m}$, the resulting arrays were essentially linear along the nominal isobath, spanned 6 to $8 \mathrm{~m}$ horizontally, had distances between adjacent units of 0.3 to $1.0 \mathrm{~m}$, and varied in depth by less than $1 \mathrm{~m}$. At $8 \mathrm{~m}$, constraints of seabed topography resulted in more haphazard arrangements of units and at all locations, actual depths ranged between 7 and $9 \mathrm{~m}$. The nominal depths (8 and $20 \mathrm{~m}$ ) are, therefore, categories, rather than precise measures.

First deployment was in late February 2001 and regular monthly exchanges were conducted until September 2001 when laboratory and dive facilities were destroyed by fire. The study was resumed in late March 2002 and 11 monthly exchanges were conducted from then up to early March 2003, when the final set of plates was retrieved.

Data analysis. Data were recorded as counts of individuals, or individual ancestrulae, recruiting to the central analysis area $\left(150 \mathrm{~cm}^{2}\right)$ of each plate surface. The range of taxa recruiting to the plates was compared with that recorded on surrounding natural substrata by contrasting the numbers of taxa recorded in each of 9 classes of sessile fauna in this study with data from Bowden (2005). Total numbers of taxa, and total numbers of individuals per plate surface summed over the 11 sampling points during 2002 to 2003, were analysed by a factorial ANOVA with depth and plate surface as fixed factors, and location as a random factor. Where interactions were significant in this analysis, locations were examined separately. Where the recruitment of individual taxa was seen to vary between plate surfaces depending on the month of immersion, repeatedmeasures ANOVA with month as the repeated measure and surface as a fixed factor was used to determine the significance of month $\times$ surface interactions. As post hoc tests are not appropriate in repeated-measures designs, where interactions were significant, 1-way ANOVAs for the effect of plate surface were run for each month of the period in question. Data distributions were examined graphically prior to analysis (Quinn \& Keough 2002) to assess normality of distribution and homogeneity of variance. Counts of the numbers of taxa were suitable for analysis without transformation but abundance data required $\log _{10}(x+1)$ transformation to meet the requirements of the analysis.

Multivariate analyses, using routines within the PRIMER statistical package (PRIMER-e), were used to examine relationships between depths, locations and month of immersion for all taxa. All multivariate analyses were conducted on fourth-root-transformed data in order to down-weight the influence of highly abundant species, and the Bray-Curtis similarity measure was used throughout. Non-metric multi-dimensional scaling (MDS) ordinations were used to visualise relationships between samples, and the taxa contributing most to dissimilarities between groups were identified by the similarities percentages routine (SIMPER). The cyclicity of seasonal patterns was tested using the RELATE correlation procedure. This technique tests for correlations between matrices of Bray-Curtis similarities generated from the sample data, and a model matrix describing a perfectly circular relationship between samples (for rationale of all procedures see Clarke \& Warwick 2001, Somerfield et al. 2002).

\section{RESULTS}

\section{Sampling}

During the entire study, 6 settlement plates (from a total of 362 individual plate deployments) were destroyed by ice impact. All of these were at $8 \mathrm{~m}$ sites: 2 plates at South Cove in April 2001, and 4 in Hangar Cove at some point between September 2001 and March 2003. In addition, Anchorage Island sites were inaccessible because of ice conditions throughout July and August 2001, and again during May and December 2002. With these exceptions, all plates were exchanged at the turn of each calendar month with a mean immersion period of $32 \mathrm{~d}$ (SD 4.9). The inaccessibility of Anchorage resulted in no data from this location for the nominal immersion periods of June, July, and August 2001, and April and November 2002. As a 
further consequence of this, Anchorage plates retrieved in early June 2002 (May immersion period) and early January 2003 (December immersion period) had been immersed for 73 and 61 d respectively, as opposed to mean immersion periods of 31 and $30 \mathrm{~d}$ at the other locations. Assemblages on these plates were qualitatively very similar to those on South Cove plates, and standardisation of the number of taxa to a uniform immersion period by halving all recorded values was not considered appropriate. Taxonomic data, therefore, have been included without adjustment. Abundances, however, were generally greater across a range of common taxa and counts have been adjusted by a factor of 0.7 . This factor, rather than 0.5 , was used to make allowance for post-settlement mortality during the extended immersion period, and was estimated from the relative proportions of single ancestrulae versus colonies with developed autozoids in common bryozoan species, particularly Celleporella antarctica.

\section{Taxon identifications}

For some taxa, identification to species level of immediate post-settlement individuals was not possible. Thus all sponges, for instance, were grouped under a single heading. In many cases, however, early recruits were distinctive enough to be assigned discrete identification codes even though their precise taxonomy could not be determined. Thus, 6 types of ascidian and 2 types of cyclostome bryozoan could be discriminated. The cheilostome bryozoan Notoplites tenuis (recorded only once) recruited as a fragment of a mature colony, attaching to the plate by means of rhizoids, but all other bryozoans recruited as ancestrulae derived from larvae. The ancestrulae of cheilostome bryozoans are distinctive and the majority of these were identified to species retrospectively by observation of colonies during the production of the first autozooids. Most cheilostome identifications were only confirmed by examination of young colonies on plates which had been left in situ for more than 1 mo, especially those left immersed during the 6 mo of the first year in which diving operations were suspended. Identifications are therefore more precise for the second year of sampling than for the first. Analyses were confined to data from the 2002 to 2003 sampling period, with the exception of year-on-year comparisons of abundances of those species for which identifications were clear from the outset. Where ancestrulae were distinctive but no firm identification could be reached, identification codes were assigned. Ancestrulae at very early stages of development were recorded under the general grouping 'indeterminate cheilostomes'.

\section{Diversity of recruiting taxa}

A total of 42 morphologically distinct sessile taxa representing 9 phyla were recorded on the plates (Table 1). This is a conservative estimate of the actual number of species recruiting, however, as groups such as sponges, cyclostome bryozoans and spirorbid polychaetes are each likely to include several species. Bryozoans were the most speciose group recorded and ancestrulae of 21 cheilostome species were identified. Together with spirorbid polychaetes, bryozoans were also the most abundant group recruiting to plates (Table 1). Twenty eight taxa (67\% of the total) occurred at all 3 locations, $9(21 \%)$ were recorded at only 2 locations, and $5(12 \%)$ were recorded at only 1 location.

The number of taxa recorded in each of the 9 principal classes of sessile fauna in the present study (2002 to 2003 data only) are compared with the corresponding numbers of taxa identified on natural substrata at each of the study sites (data from Bowden 2005) in Fig. 2. At this level, recruiting assemblages at all sites appear to be broadly representative of the surrounding biota. Brachiopods (class Articulata) are the only taxon which is completely unrepresented on the settlement plates but the Anthozoa are also under-represented, largely due to the absence of Alcyonium antarcticum recruitment to the plates. The apparent paucity of sponge taxa on the settlement plates, however, is probably caused by the inability to distinguish between taxa at very early recruitment stages, as noted above.

\section{Seasonal patterns of recruitment}

MDS ordinations of Bray-Curtis similarities between the average assemblage recruiting in each month show a cyclical progression through the $11 \mathrm{mo}$ of the second year of the study at each location $\times$ depth combination (Fig. 3). Thus, late-summer assemblages recruiting in February 2003 were more similar to late summer assemblages recruiting in April 2002 than to those recruiting in the intervening winter or early summer. Correlations of the similarity matrices underlying these ordinations with a model matrix representing an idealised circular relationship between samples (RELATE procedure in PRIMER) are significant $(p<0.001)$ in all cases, suggesting that the assemblages recruiting through the year follow a predictable annual pattern.

Comparisons of the mean number of taxa recruiting per surface in each month (Fig. 4) show that recruitment took place throughout the year but that patterns were not consistent across locations. Hangar Cove assemblages exhibited a distinct seasonality of recruit- 
Table 1. Sessile taxa recruiting to settlement plates at $20 \mathrm{~m}$ and $8 \mathrm{~m}$ depths over the period April 2002 to March 2003. Abundance classes for the total number of recruits summed over all months at each site (total surface area per site: $1800 \mathrm{~cm}^{2}$ ) are represented

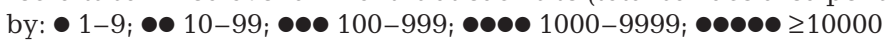

\begin{tabular}{|c|c|c|c|c|c|c|c|c|}
\hline \multirow{3}{*}{ Phylum } & \multirow[t]{3}{*}{ Class } & \multirow[t]{3}{*}{ Taxon } & \multicolumn{6}{|c|}{ Location and depth } \\
\hline & & & \multicolumn{2}{|c|}{ Hangar } & \multicolumn{2}{|c|}{ South } & \multicolumn{2}{|c|}{ Anchorage } \\
\hline & & & $20 \mathrm{~m}$ & $8 \mathrm{~m}$ & $20 \mathrm{~m}$ & $8 \mathrm{~m}$ & $20 \mathrm{~m}$ & $8 \mathrm{~m}$ \\
\hline Porifera & Demospongiae & Sponges & $\bullet$ & $\bullet \bullet$ & $\bullet \bullet$ & & $\bullet$ & \\
\hline Rhizopoda & & Foraminiferans & $\bullet$ & $\bullet$ & $\bullet$ & $\bullet$ & $\bullet \bullet$ & $\bullet$ \\
\hline Ciliophora & Polyhymenophora & Folliculina spp. & $\bullet$ & & $\bullet$ & $\bullet \bullet \bullet$ & $\bullet \bullet$ & $\bullet \bullet$ \\
\hline Cnidaria & $\begin{array}{l}\text { Hydroida } \\
\text { Alcyonaceae }\end{array}$ & $\begin{array}{l}\text { Hydrozoans } \\
\text { Primnoella sp. } \\
\text { Indet. cnidarian }\end{array}$ & $\bullet \bullet \bullet$ & $\bullet \bullet$ & $\bullet \bullet$ & $\bullet \bullet$ & $\stackrel{\bullet \bullet}{\bullet}$ & $\bullet$ \\
\hline Annellida & Polychaeta & $\begin{array}{l}\text { Serpulids } \\
\text { Spirorbids }\end{array}$ & $\stackrel{\bullet \bullet \bullet}{\bullet \bullet \bullet \bullet \bullet ~}$ & $\stackrel{\bullet \bullet}{\bullet \bullet \bullet \bullet ~}$ & $\stackrel{\bullet \bullet \bullet}{\bullet \bullet \bullet \bullet \bullet ~}$ & $\stackrel{\bullet \bullet}{\bullet \bullet \bullet \bullet}$ & $\bullet \bullet \bullet$ & $\bullet \bullet$ \\
\hline Mollusca & Bivalvia & $\begin{array}{l}\text { Adamussium colbecki } \\
\text { Philobrya sublaevis }\end{array}$ & $\bullet$ & & $\bullet$ & $\bullet$ & $\bullet$ & \\
\hline \multirow[t]{13}{*}{ Bryozoa } & Stenolaemata & $\begin{array}{l}\text { Cyclostome } 1 \\
\text { Cyclostome } 2\end{array}$ & $\bullet \bullet$ & $\bullet \bullet$ & $\stackrel{\bullet \bullet}{\bullet \bullet}$ & $\stackrel{\bullet}{\bullet \bullet}$ & 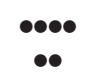 & $\bullet \bullet$ \\
\hline & Gymnolaemata & $\begin{array}{l}\text { Aimulosia antarctica } \\
\text { Hippadanella inerma } \\
\text { Arachnopusia inchoata } \\
\text { Chaperiopsis protecta } \\
\text { Fenestrulina rugula } \\
\text { Micropora notialis } \\
\text { Micropora brevissima }\end{array}$ & $\begin{array}{c}\bullet \bullet \\
\bullet \\
\bullet \bullet \\
\bullet \bullet \\
\bullet \bullet \bullet\end{array}$ & $\begin{array}{c}\bullet \\
\bullet \bullet \\
\bullet \bullet \bullet \\
\bullet \bullet \bullet \bullet \\
\bullet \bullet \bullet \\
\bullet\end{array}$ & $\begin{array}{c}\bullet \bullet \\
\bullet \\
\bullet \bullet \\
\bullet \bullet \\
\bullet \bullet\end{array}$ & $\begin{array}{c}\bullet \bullet \\
\bullet \\
\bullet \\
\bullet \\
\bullet \bullet \\
\bullet\end{array}$ & $\begin{array}{c}\bullet \bullet \\
\bullet \\
\bullet \bullet \\
\bullet \bullet \\
\bullet \bullet\end{array}$ & $\begin{array}{c}\bullet \bullet \bullet \\
\bullet \\
\bullet \\
\bullet \bullet \\
\bullet\end{array}$ \\
\hline & & $\begin{array}{l}\text { Celleporella antarctica } \\
\text { Celleporella dictyota }\end{array}$ & $\bullet$ & $\bullet$ & $\stackrel{\bullet \bullet \bullet}{\bullet}$ & $\bullet \bullet \bullet$ & $\bullet \bullet \bullet$ & $\bullet \bullet \bullet$ \\
\hline & & Celleporella bouganvillei & $\bullet$ & & $\bullet$ & $\bullet$ & $\bullet \bullet$ & $\bullet \bullet$ \\
\hline & & $\begin{array}{l}\text { Beania erecta } \\
\text { Camptoplites bicornis } \\
\text { Osthimosia sp. } \\
\text { Figularia discors }\end{array}$ & $\bullet$ & $\bullet$ & $\bullet$ & $\bullet$ & $\begin{array}{l}\bullet \bullet \\
\bullet \\
\bullet \bullet \\
\bullet\end{array}$ & $\stackrel{\bullet}{\bullet}$ \\
\hline & & Smittina sp. & $\bullet$ & $\bullet$ & $\bullet$ & $\bullet$ & & $\bullet$ \\
\hline & & Ellisina antarctica & $\bullet \bullet$ & $\bullet \bullet$ & $\bullet \bullet$ & $\bullet \bullet$ & $\bullet \bullet \bullet$ & $\bullet \bullet$ \\
\hline & & $\begin{array}{l}\text { Lageneschara lyrulata } \\
\text { Notoplites tenuis }\end{array}$ & $\bullet$ & $\bullet$ & $\bullet$ & & $\bullet$ & \\
\hline & & Inversiula nutrix & $\bullet$ & & & & $\bullet$ & $\bullet$ \\
\hline & & Erect cheilostome 2 & $\bullet$ & & $\bullet$ & & $\bullet$ & \\
\hline & & Erect cheilostome 4 & & & $\bullet$ & & $\bullet$ & \\
\hline & & Indet. ancestrula type 5 & & & $\bullet$ & & $\bullet$ & \\
\hline & & Indet. cheilostomes & $\bullet \bullet$ & $\bullet$ & $\bullet \bullet$ & $\bullet$ & $\bullet \bullet \bullet$ & $\bullet \bullet$ \\
\hline Chordata & Ascidacea & Solitary Ascidian 1 & $\bullet$ & $\bullet$ & $\bullet \bullet \bullet$ & $\bullet \bullet$ & $\bullet \bullet \bullet$ & $\bullet \bullet$ \\
\hline & & Solitary Ascidian 2 & $\bullet$ & $\bullet$ & $\bullet \bullet$ & $\bullet$ & $\bullet \bullet$ & $\bullet \bullet$ \\
\hline & & Solitary Ascidian 3 & & & $\bullet$ & $\bullet$ & $\bullet \bullet$ & \\
\hline & & Solitary Ascidian 4 & $\bullet \bullet$ & & $\bullet \bullet$ & & $\bullet \bullet$ & \\
\hline & & Solitary Ascidian 5 & & & $\bullet$ & $\bullet$ & $\bullet$ & $\bullet$ \\
\hline & & Compound Ascidian 1 & $\bullet \bullet$ & $\bullet$ & $\bullet$ & $\bullet$ & $\bullet$ & $\bullet$ \\
\hline Rhodophyta & Florideophyceae & Coralline algae & $\bullet \bullet \bullet$ & $\bullet$ & $\bullet \bullet \bullet$ & $\bullet$ & $\bullet \bullet \bullet$ & $\bullet \bullet$ \\
\hline
\end{tabular}

ment, with greater mean numbers of taxa recruiting in the summer months (November to February) and a mid-winter (June to July) minimum. South Cove recruitment was more uniform throughout the year, with poorly defined trends towards a summer maximum at $8 \mathrm{~m}$ and a winter maximum at $20 \mathrm{~m}$. Anchorage recruitment at $20 \mathrm{~m}$ showed a pronounced latewinter (July to September) maximum, with the highest mean taxon richness recorded at any site, for any month $(14.3 \pm 1.05$, mean $\pm \mathrm{SE})$, recruiting to upper plate surfaces during August. In plots of the total number of taxa recruiting per month (Fig. 4, thick line), this late-winter pulse of recruiting taxa was evident at all $20 \mathrm{~m}$ sites but was not clear at $8 \mathrm{~m}$ sites. SIMPER analyses comparing recruitment in winter (June to August) with that in summer (December to February) (Table 2) indicated that the winter peak was associated with a range of taxa including solitary ascidians, cheilostome 

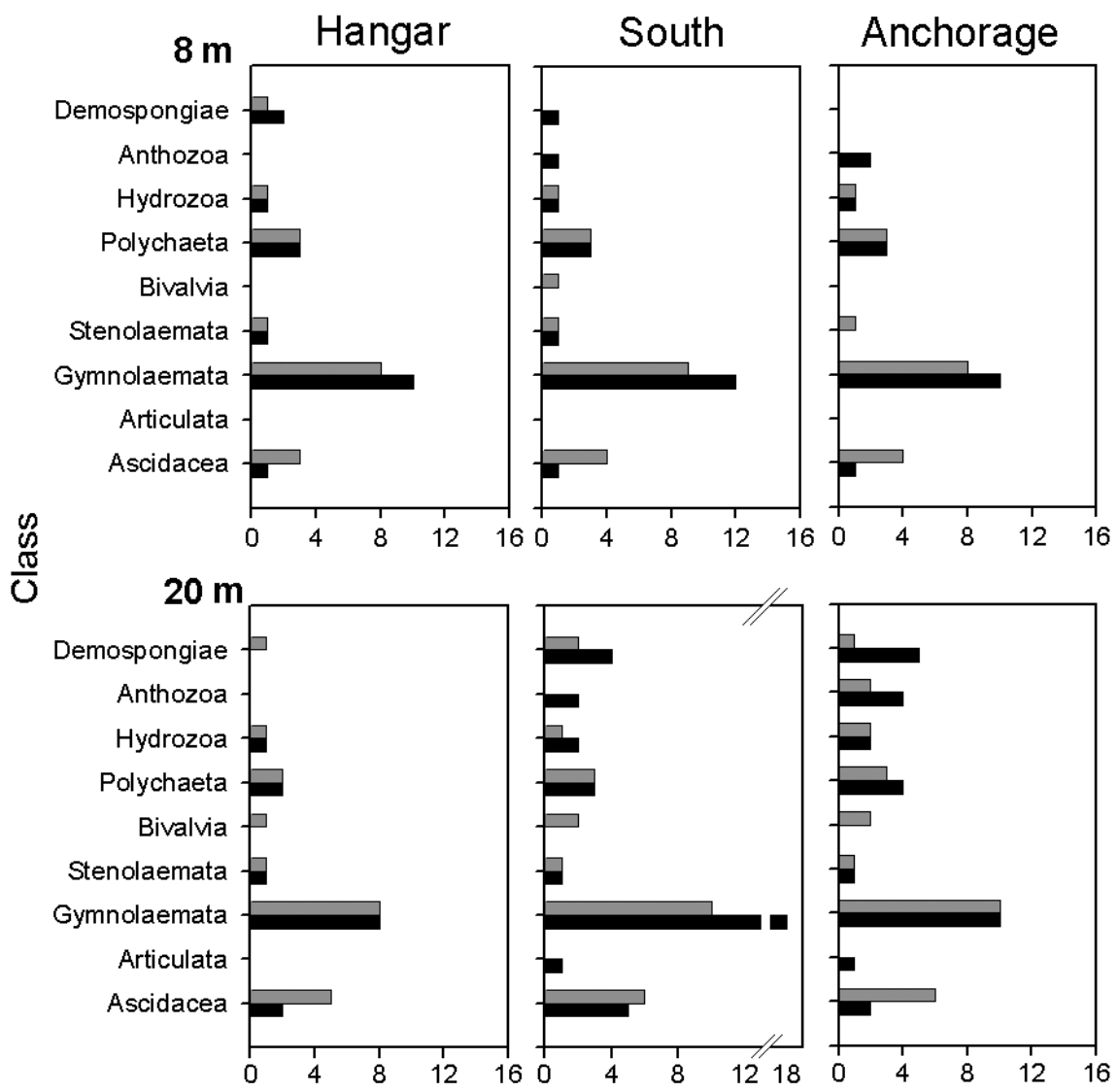

on natural substrata recruiting to plates

Number of taxa recorded

Fig. 2. Numbers of taxa recorded on natural substrata (black bars) and recruiting to artificial substrata (grey bars) in the 9 major classes of sessile macrofauna present in the study area. Natural substrata data are from Bowden (2005), recruitment data are from 2002 to 2003 in the present study

bryozoans, cnidarians and thecate protozoans, many of which recruited in low abundances and thus exerted little influence on the mean values plotted in Fig. 4.

Monthly abundances of individual species and taxa (Figs. $5 \& 6$ ) show distinct seasonality of recruitment in most cases and, where data from the 2 sampling periods overlap, there is evidence that recruitment patterns were similar in consecutive years (Fig. 5). Across the range of taxa sampled, there are examples of both year-round and highly seasonal recruitment, and of peak recruitment taking place in all months of the year other than June (mid-winter). Peak recruitment of individual cheilostome bryozoan species, with the exception of Celleporella sp. and Aimulosia antarctica, was generally restricted to periods of 1 or 2 mo and, in all species, took place in the period from July to January, encompassing the second half of the winter through to mid-summer. Peak recruitment of all ascidian species also occurred during this period: of the 6 species recorded, 4 recruited in winter and 2 in mid-summer.
Fig. 6 shows recruitment of 8 cheilostome bryozoan species grouped by their rankings in a hierarchy of competitive overgrowth abilities as determined by Barnes \& Rothery (1996) for bryozoan assemblages at Signy Island. The left panel shows recruitment of 4 strongly competitive species and the right panel shows recruitment of 4 weakly competitive species. Within each panel, species are further ranked from top to bottom in order of decreasing competitive ability (Barnes \& Rothery 1996 and D. K. A. Barnes pers. comm.). Comparison of peak recruitment periods in relation to the mid-summer datum (dotted line) shows that the group of weaker competitors recruited earlier in the year than the stronger competitors.

\section{Spatial patterns of recruitment}

Total numbers of sessile faunal individuals and total numbers of sessile faunal taxa recorded per plate surface for the period April 2002 to February 2003 are compared in Figs. 7 \& 8. Recruitment took place on both upper and lower plate surfaces, but the distribution of recruitment between surfaces differed markedly with depth and location.

The total number of individuals showed a significant interaction between surface and depth (ANOVA $F_{1,2}=46.58, \mathrm{p}=0.021$ ), with consistently greater recruitment to upper surfaces at $20 \mathrm{~m}$ and to lower surfaces at $8 \mathrm{~m}$. However, this interaction was driven largely by differential recruitment of spirorbids. When this taxon was removed from the analysis (lower bars in Fig. 7) the pattern was more varied. At $8 \mathrm{~m}$, numbers of recruits were not significantly different between plate surfaces at Anchorage and South Cove, but were significantly greater on lower surfaces at Hangar Cove. At $20 \mathrm{~m}$, numbers of recruits were significantly greater on upper surfaces at Anchorage and South Cove, but again significantly greater on lower surfaces at Hangar Cove.

Across all locations and for both plate surfaces, the total number of taxa recorded was significantly greater at $20 \mathrm{~m}$ than at $8 \mathrm{~m}$ (ANOVA $F_{1,2}=45.56, \mathrm{p}=0.021$ ). However, there was a strong interaction between depth, surface and location (ANOVA $F_{1,60}=10.57, \mathrm{p}<0.001$ ) 

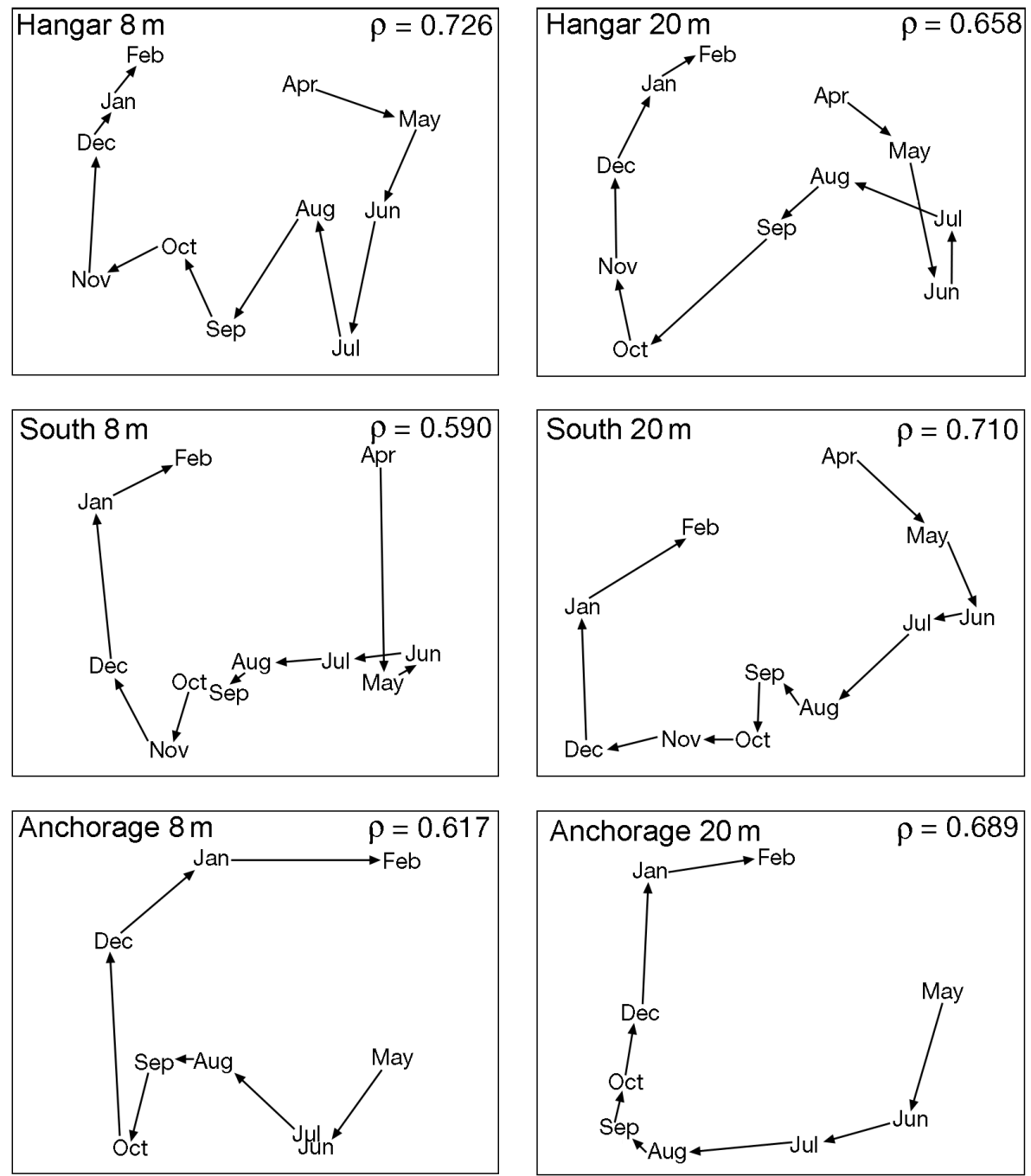

Fig. 3. MDS ordinations of monthly recruitment to settlement plates at Hangar Cove, South Cove, and Anchorage from April 2002 to February 2003. Plots represent the monthly average assemblage recruiting to both surfaces of all plates for each depth at each location. Underlying matrices of BrayCurtis similarity are derived from recruitment data for all taxa averaged by site and fourth-roottransformed. RELATE values $(\rho)$ are shown for the strength of correlations with an idealized cyclical matrix. All correlations are significant at $\mathrm{p}<0.001$, indicating that recruiting assemblages follow a predictable annual pattern. Stress values are $\leq 0.06$ for all ordinations caused by much greater numbers of taxa recruiting to upper than lower surfaces of Anchorage $20 \mathrm{~m}$ plates. At $8 \mathrm{~m}$, significantly more taxa recruited to lower surfaces than upper surfaces of Hangar Cove and Anchorage plates, but at South Cove this difference was not statistically significant (ANOVA $F_{1,10}=3.02, \mathrm{p}=0.11$ ). At $20 \mathrm{~m}$, significantly more taxa recruited to lower surfaces of South Cove and Hangar Cove plates, but at Anchorage significantly more taxa recruited to upper surfaces.

Thus, while significantly more taxa recruited at $20 \mathrm{~m}$ than at $8 \mathrm{~m}$, there was no clear generality of pattern across locations in either the total number of individuals or the total number of taxa recruiting to upper and lower plate surfaces. However, even where differences between surfaces are statistically significant, it is clear that recruitment to both surfaces was substantial in terms of both numbers of taxa and numbers of individuals.

Table 3 shows the results of SIMPER analyses, pooled across all months, identifying the taxa contributing most (90\% cut-off) to the dissimilarity between assemblages recruiting to upper and lower surfaces at each location. The proportion of these taxa recorded in greater numbers on upper plate surfaces varied across locations but was consistently greater at $20 \mathrm{~m}$ than at $8 \mathrm{~m}$. This effect was most pronounced at Anchorage, where $88 \%$ of taxa differentiating between surfaces at $20 \mathrm{~m}$ were recorded in greater numbers on upper surfaces. Other than coralline algae, which recruited only to upper surfaces, there were no species which recruited exclusively to either upper or lower surfaces across all sites, and for most species the proportion of recruitment to each surface varied with depth and across locations. Recruitment of spirorbid polychaetes and cyclostome bryozoans showed an interaction between depth and plate surface: numbers of recruits of these taxa were greater on lower surfaces at $8 \mathrm{~m}$ depth, but greater on upper surfaces at $20 \mathrm{~m}$ depth.

The relative numbers of taxa recruiting to upper and lower plate surfaces were not consistent through the 
year (means plots in Fig. 4). At all 8 m sites, similar numbers of taxa recruited to upper and lower surfaces throughout the winter period (May to October). During the summer months (November to January), however, there was a pronounced decline in the relative number of taxa recorded on upper surfaces. At $20 \mathrm{~m}$, this pattern was not clear and recruitment to upper and lower surfaces at Hangar Cove and South Cove was generally similar throughout the year. At the Anchorage $20 \mathrm{~m}$ site, however, the numbers of recruiting taxa recorded were significantly higher on upper surfaces in all but 1 (December) of the 9 mo sampled.

Examination of individual species' abundances showed that the decrease in taxa recruiting to upper plate surfaces at $8 \mathrm{~m}$ during the summer months at South Cove and Anchorage (Fig. 4) was associated with declines in the abundances of several taxa. This effect was most pronounced for hydroids, coralline algae, cyclostome bryozoans, Ellisina antarctica, Camptoplites bicor- nis, and Fenestrulina rugula. To illustrate this, Fig. 9 shows the relative abundance of $F$. rugula recruits recorded on upper and lower plate surfaces in South Cove during 2002 to 2003. From August to October, at both depths, recruitment to upper surfaces was not significantly different from, or greater than, recruitment to lower surfaces (1-way ANOVA, p > 0.1 in all cases except August $20 \mathrm{~m}, \mathrm{p}=0.049$ ). However, from November to January at $8 \mathrm{~m}$, and from November to December at $20 \mathrm{~m}$, recruitment to upper surfaces was significantly less than that to lower surfaces ( $p<0.02$ in all cases).

\section{DISCUSSION}

These data show that recruitment of sessile invertebrates to hard substrata in a near-shore Antarctic location took place throughout the year. However, most taxa exhibited pronounced seasonality of recruitment
Fig. 4. Total numbers of faunal taxa (species and other taxa: Table 1) recruiting at each study site, and mean numbers of taxa recruiting to upper and lower surfaces of settlement plates at 2 depths (8 and $20 \mathrm{~m}$ ) and 3 locations (Hangar, South, Anchorage) between April 2002 and February 2003. Plates were immersed for $32 \pm 4.9 \mathrm{~d}$ (mean \pm $\mathrm{SD})$. Plotted values are means, error bars are $1 \mathrm{SE}, \mathrm{n}=6$. Note: Anchorage data for May and December are from plates immersed for 73 and $61 \mathrm{~d}$, respectively
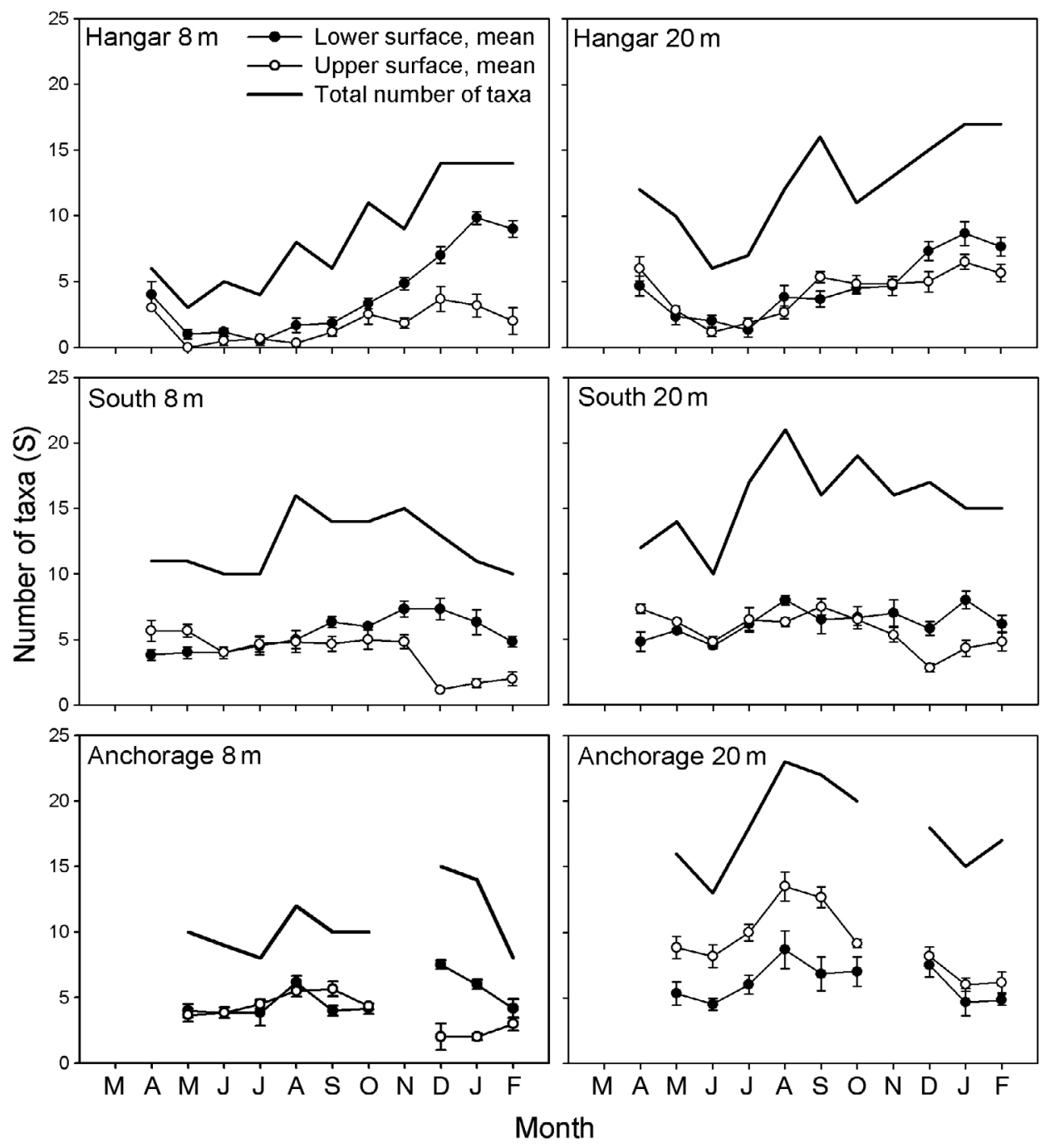
and, when viewed overall, recruiting assemblages followed a cyclical pattern through the year, suggesting an annual pattern of reproduction for most taxa. For many taxa, the period of recruitment did not coincide with the summer pulse of primary production and many recruited during winter. Therefore, the hypothesis that recruitment of the majority of taxa coincides with the period of maximum food availability is not supported. The results also show that more taxa recruited at $20 \mathrm{~m}$ than at $8 \mathrm{~m}$, and that total recruitment to upward-facing surfaces was substantial and comparable with that to downward-facing surfaces. Thus, the data support the hypothesis that the diversity of recruitment decreases with decreasing depth, but do not support the hypothesis that there is greater recruitment to downward-facing surfaces.

Table 2. Taxa contributing to the dissimilarity between assemblages recruiting in summer (December to February) and winter (June to August) with indication of taxa recruiting only in summer $(0)$ or only in winter $(\bullet)$. Taxa are in order of decreasing contribution to overall dissimilarity between seasons in a SIMPER analysis based on presence/absence transformed data. Abundance data (average number of recruits $150 \mathrm{~cm}^{-2}$ across all locations and depths) are given as untransformed values

\begin{tabular}{|c|c|c|c|c|c|}
\hline \multirow[t]{2}{*}{ Taxon } & & \multicolumn{2}{|c|}{$\begin{array}{c}\text { Average number } \\
\text { of recruits }\left(150 \mathrm{~cm}^{-2}\right)\end{array}$} & \multirow[t]{2}{*}{$\begin{array}{c}\text { Average } \\
\text { dissimilarity }\end{array}$} & \multirow[t]{2}{*}{$\begin{array}{l}\text { Dissim. } \\
\text { SD }\end{array}$} \\
\hline & & Jun-Aug & Dec-Feb & & \\
\hline \multicolumn{6}{|l|}{ Summer } \\
\hline Serpulids & o & 0.00 & 2.71 & 3.61 & 0.74 \\
\hline Micropora notialis & & 0.03 & 1.67 & 2.72 & 0.65 \\
\hline Solitary ascidian 1 & & 0.13 & 0.51 & 2.10 & 0.51 \\
\hline Arachnopusia inchoata & & 0.02 & 0.57 & 1.81 & 0.53 \\
\hline Chaperiopsis protecta & & 0.06 & 0.70 & 1.59 & 0.50 \\
\hline Sponges & & 0.08 & 0.87 & 1.49 & 0.40 \\
\hline Beania erecta & o & 0.00 & 0.58 & 1.43 & 0.44 \\
\hline Compound ascidian 1 & 0 & 0.00 & 0.20 & 0.98 & 0.36 \\
\hline Smittina sp. & & 0.02 & 0.10 & 0.65 & 0.28 \\
\hline Adamussium colbecki & O & 0.00 & 0.08 & 0.31 & 0.19 \\
\hline Lageneschara lyrulata & ० & 0.00 & 0.01 & 0.04 & 0.07 \\
\hline \multicolumn{6}{|l|}{ Winter } \\
\hline Celleporella antarctica & & 15.75 & 1.22 & 5.70 & 0.92 \\
\hline Solitary ascidian 5 & & 0.49 & 0.02 & 2.80 & 0.56 \\
\hline Hydrozoans & & 0.51 & 0.07 & 2.19 & 0.46 \\
\hline Folliculina spp. & $\bullet$ & 0.95 & 0.00 & 1.78 & 0.46 \\
\hline Solitary ascidian 2 & & 0.19 & 0.03 & 0.61 & 0.30 \\
\hline Osthimosia sp. & & 0.22 & 0.02 & 0.51 & 0.28 \\
\hline Figularia discors & $\bullet$ & 0.07 & 0.00 & 0.35 & 0.23 \\
\hline Solitary ascidian 3 & $\bullet$ & 0.13 & 0.00 & 0.31 & 0.22 \\
\hline Solitary ascidian 4 & & 0.18 & 0.01 & 0.30 & 0.21 \\
\hline Philobrya sublaevis & $\bullet$ & 0.04 & 0.00 & 0.17 & 0.14 \\
\hline Indet. cheilostome 5 & $\bullet$ & 0.03 & 0.00 & 0.15 & 0.15 \\
\hline Erect cheilostome 2 & $\bullet$ & 0.04 & 0.00 & 0.14 & 0.16 \\
\hline Indet. cheilostome 6 & $\bullet$ & 0.01 & 0.00 & 0.08 & 0.10 \\
\hline Inversiula nutrix & $\bullet$ & 0.01 & 0.00 & 0.07 & 0.10 \\
\hline Notoplites tenuis & $\bullet$ & 0.01 & 0.00 & 0.04 & 0.07 \\
\hline Indet. cnidarian & $\bullet$ & 0.01 & 0.00 & 0.03 & 0.07 \\
\hline Primnoella sp. & - & 0.02 & 0.00 & 0.02 & 0.07 \\
\hline
\end{tabular}

For the majority of taxa recorded, the present data suggest an annual cycle of reproduction and recruitment (Fig. 3). The relatively short duration of the study, however, does not allow it to discount the possibility of significant inter-annual variability, or of episodic recruitment events, as described by Dayton (1989) for the sponge Homaxinella balfourensis in McMurdo Sound. Although recruitment to artificial substrata in the present study appears to be broadly representative of sessile assemblages in the area (Fig. 2), some sessile species known to be present at the experimental locations (Bowden 2005) were not recorded on the settlement plates. While this might be as a result of larval settlement preferences, patchy distributions, or restricted dispersal, it is also possible that the reproductive cycles of these species are not annual, or that the supply of larvae is affected by nonannual physical fluctations.

Considering the extreme seasonality of primary production in high-latitude marine environments (Arntz et al. 1994, Clarke \& Leakey 1996), it is perhaps surprising that there is no evidence of a single optimal period for reproduction amongst the sessile suspension-feeding taxa recorded here. Indeed, when compared simply in terms of the total number of taxa recruiting, assemblages in temperate latitudes appear to show more pronounced seasonality and synchronisation with the summer bloom than the high latitude assemblages studied here. Moreover, peak taxon richness at $20 \mathrm{~m}$ in the present study was recorded in winter. Although there are few studies worldwide with comparable year-round sampling, and none at comparable depths, data from 3 recruitment studies in the immediate sublittoral in the North Atlantic (Fig. 10) suggest that this is the opposite of the pattern seen in temperate assemblages.

Most of the taxa recruiting in this study, notably bryozoans, ascidians and sponges, reproduce by means of nonfeeding, lecithotropic larval stages (Hayward 1995, Todd 1998, Young 2002) and their spawning might thus be expected to be decoupled to some extent from the summer pulse of primary productivity. As these taxa share similar feeding modes and are of similar sizes at settlement, however, it might still be predicted that there 
Fig. 5. Recruitment of selected sessile taxa to settlement plates during the years 2001 and 2002/2003. Data are means across all locations, depths, and surfaces, $\mathrm{n}=72$, except June to August 2001 and April and December $2002 \mathrm{n}=48$ error bars are $1 \mathrm{SE}$
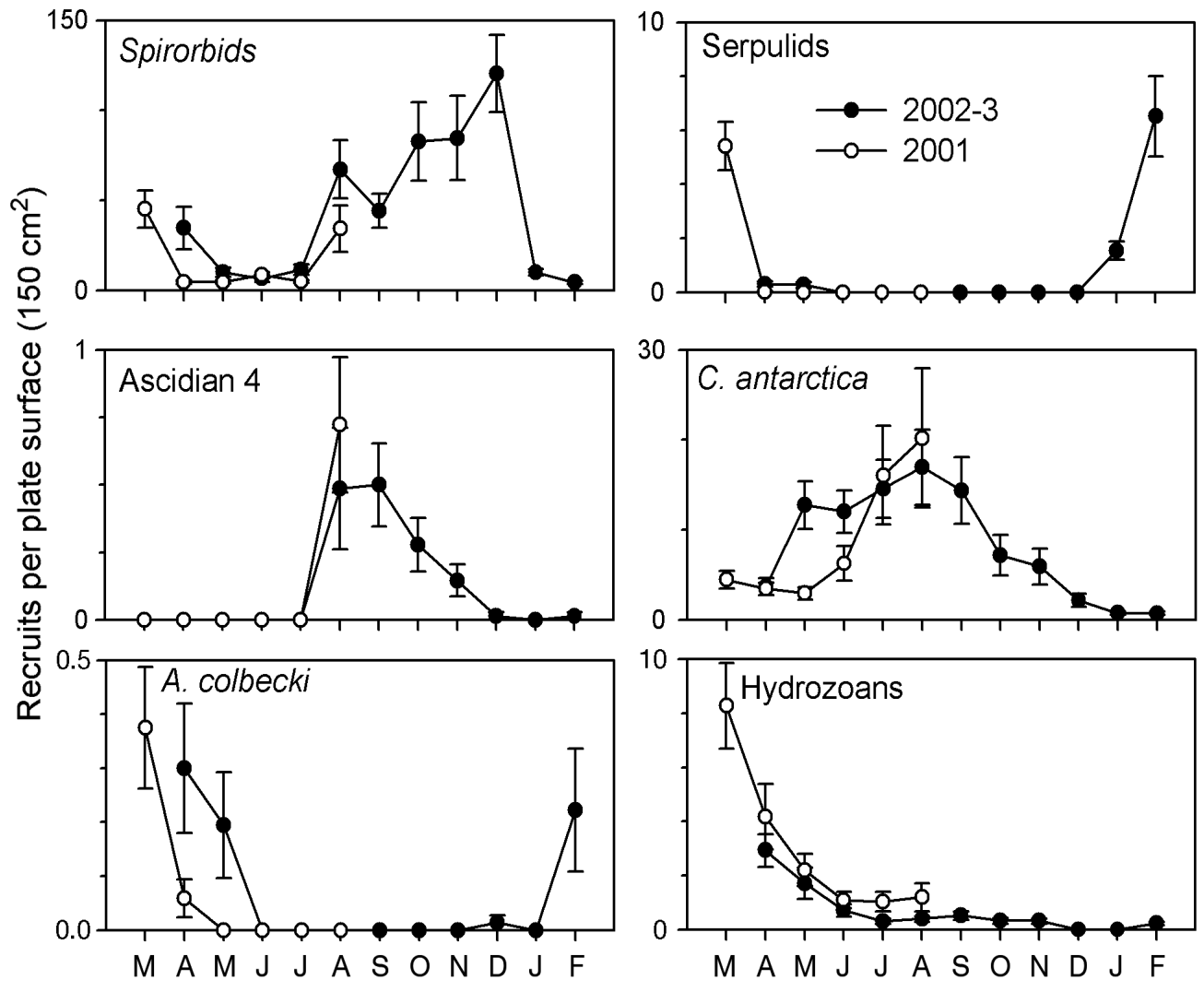

would be a common optimal time of settlement. Yet, peak recruitment periods of cheilostome bryozoans and ascidians recorded in this study are distributed from mid-winter through to late summer, and may be either brief or extended. For cheilostome bryozoans, a similar recruitment period has been reported in the maritime Antarctic (Stanwell-Smith \& Barnes 1997), and the common Antarctic ascidian Cnemidocarpa verrucosa has been shown to spawn in winter at King George Island (Sahade et al. 2004), suggesting that these patterns may be general in Antarctic waters and thus that the summer phytoplankton bloom is not the principal cue for reproduction in these taxa.

This, in turn, suggests that the months of the Antarctic winter may not be as limiting to survival as one might think. There are 2 lines of research which may combine to explain this. Firstly, physiological studies of vagile benthic species in the Antarctic have shown that very low resting metabolic rates resulting from low seawater temperatures enable overwintering with negligible loss of tissue mass (Brockington 2001, Brockington \& Clarke 2001). Thus, the energetic cost of survival following winter settlement in sessile species may also be very low. Secondly, it has been demonstrated that several species of Antarctic bryozoan feed for all but a short period ( 2 to $3 \mathrm{mo}$ ) of the year (Barnes \& Clarke 1995), utilising the nanoplanktonic fraction (2 to $20 \mu \mathrm{m}$ ) of primary production which persists at low levels through the winter months (Clarke \& Leakey 1996). Similarly, the winter-spawned planktotrophic larvae of the asteroid Odontaster validus, and the nemertean Parborlasia corrugatus, both abundant in Antarctic coastal waters, have been shown to feed and grow through the winter months on this fraction of primary productivity (Rivkin et al. 1986, Bosch \& Rivkin 1988, Pearse et al. 1991a). Thus, foodlimitation does not appear to be a critical restriction for bryozoans or larvae during the austral winter, and, by extension, may not be for the smallest juvenile stages of other sessile suspension-feeding organisms. Adult solitary ascidians, for instance, consume a wide range of food particle sizes from 1 1 m upwards (Randlov \& Riisgard 1979, Bingham \& Walters 1989, Kowalke 1999), but recently metamorphosed juveniles are too small to take in the larger phytoplankton cells which are characteristic of the austral summer bloom. Nanoplankton is, therefore, likely to be a significant food source for ascidians during the immediate post-settlement period and, thus, there may be no nutritional disadvantage to winter settlement. That 4 out of the 6 ascidian types recorded here recruited exclusively in winter lends weight to this argument. 


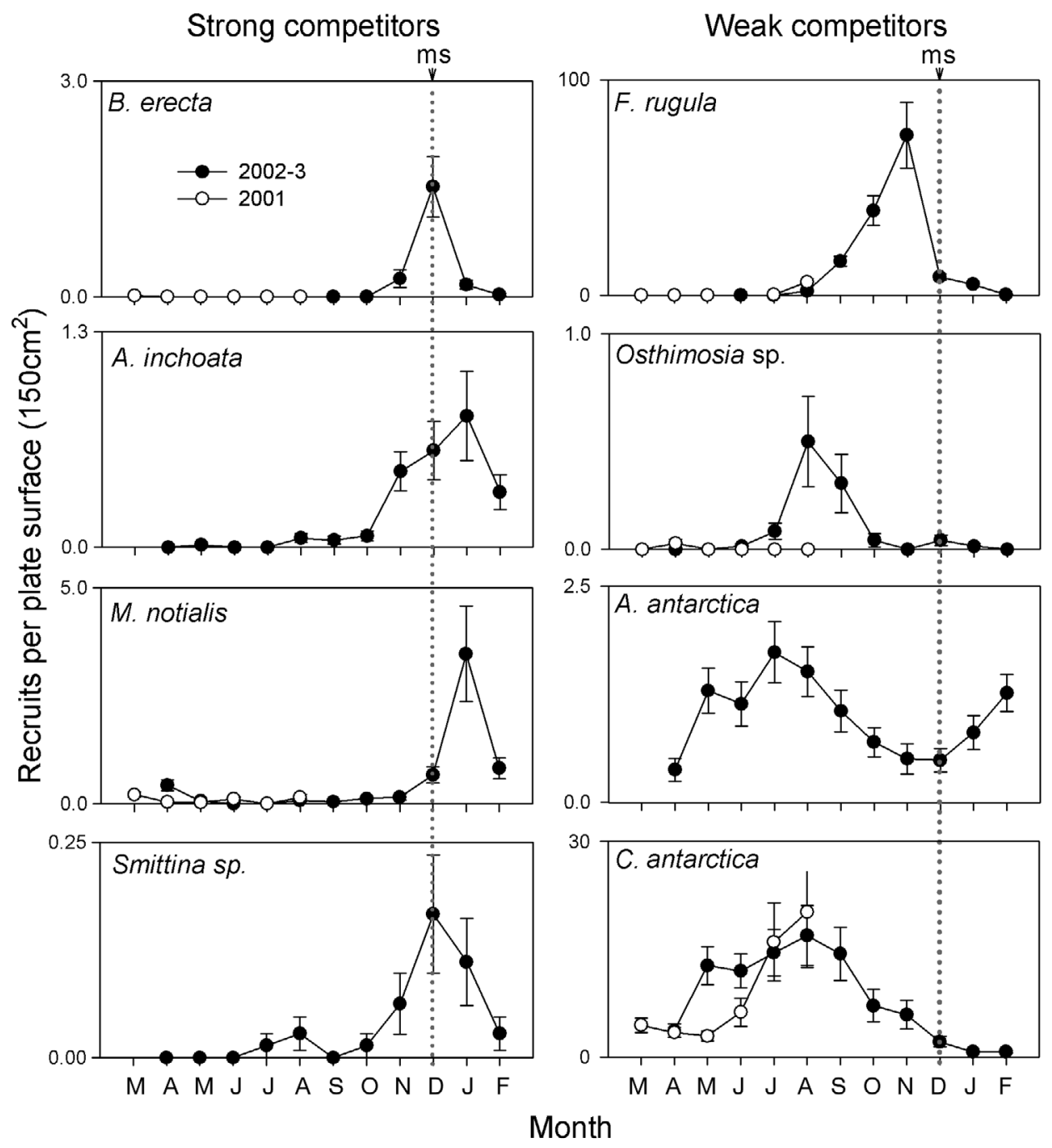

Fig. 6. Timing of peak recruitment period in relation to overgrowth competition strength for selected cheilostome bryozoan species. Left and right panels, respectively, show recruitment of 4 strongly competitive and 4 weakly competitive species. Within each panel, species are ranked from top to bottom in order of decreasing competitive ability (rankings follow the hierarchy of overgrowth competition strength in Barnes \& Rothery 1996). The dotted lines 'ms' indicate mid-summer. Where reliable identifications were available in the first year of the study, data for both 2001 and 2002 to 2003 are shown. Data are means across all locations, depths, and plate surfaces, $\mathrm{n}=72$, except June to August 2001 and April and December $2002 \mathrm{n}=48$, error bars are $1 \mathrm{SE}$
More compelling adaptive reasons for recruitment to take place during the winter might be found in greater availability of free substratum and reduced mortality at this time of year; both factors being principally related to the activities of macrobenthic grazers, and suspension and deposit feeders. Nearshore Antarctic waters support high abundances of such taxa (Kirkwood \& Burton 1988, Dayton 1990, Arntz et al. 1994, Barnes \& Brockington 2003). During the summer bloom, the seabed at shallower depths is dominated by limpets and urchins, while below $\sim 15 \mathrm{~m}$ extensive areas are covered by the feeding tendrils of terebellid polychaetes and holothurians. In the present study, urchins, limpets, and asteroids were numerous on plate upper surfaces, while holothurians, terebellids and nemerteans were often found inhabiting the space between plate undersurfaces and the base panel. These taxa are active during the highly productive months of the summer bloom but many, particularly the suspension and deposit feeders and the urchin Sterechinus neumayeri, are largely inactive through the rest of the year (Brockington et al. 2001 and author's pers. obs.). The probability of a settling larva encountering clear substratum, and subsequently avoiding death by grazing or smothering, is therefore higher in winter than in summer.

Ice-mediated disturbance of the seabed, which is responsible for considerable mortality of benthic fauna in polar seas (Gutt et al. 1996, Barnes 1999, Peck et al. 1999, Gutt 2001, Brown et al. 2004), is also reduced or absent in winter when the surface waters freeze. Although the frequency of occurrence of winters in which fast-ice forms appears to be decreasing at this latitude on the West Antarctic Peninsula (Vaughan et al. 2003), over evolutionary timescales the seasonal variation of disturbance caused by the winter freezing and summer break-up of fast ice is likely to have influenced the evolution of present day life-history strategies. That is, increased disturbance by ice in summer may exert a selective pressure towards winter settlement in sessile taxa. 


\begin{tabular}{|c|c|c|c|c|c|c|}
\hline \multirow[t]{2}{*}{ Depth } & \multirow[t]{2}{*}{ Taxon } & \multicolumn{3}{|c|}{$\begin{array}{c}\text { No. of recruits } \\
\text { per } 150 \mathrm{~cm}^{2} \text { surface }\end{array}$} & \multirow[t]{2}{*}{$\begin{array}{l}\text { Mean dis- } \\
\text { similarity }\end{array}$} & \multirow[t]{2}{*}{$\begin{array}{l}\text { Dissimil- } \\
\text { arity/SD }\end{array}$} \\
\hline & & & & & & \\
\hline \multicolumn{7}{|c|}{ Hangar Cove } \\
\hline \multirow{7}{*}{$8 \mathrm{~m}$} & Spirorbids & - & 31.93 & 18.98 & 15.6 & 1.17 \\
\hline & Fenestrulina rugula & & 11.14 & 25.23 & 14.46 & 0.91 \\
\hline & Cyclostome 2 & & 0.64 & 1.38 & 5.17 & 0.77 \\
\hline & Sponges & & 0.19 & 3.42 & 5.17 & 0.83 \\
\hline & Hydroids & - & 0.98 & 0.00 & 4.87 & 0.48 \\
\hline & Micropora notialis & & 0.33 & 4.79 & 4.63 & 0.86 \\
\hline & Chaperiopsis protecta & & 0.05 & 2.35 & 3.73 & 0.82 \\
\hline \multirow[t]{11}{*}{$20 \mathrm{~m}$} & Spirorbids & $\bullet$ & 154.22 & 15.61 & 10.94 & 1.10 \\
\hline & Fenestrulina rugula & & 16.94 & 52.27 & 10.10 & 1.00 \\
\hline & Hydroids & - & 1.66 & 0.00 & 5.05 & 0.86 \\
\hline & Cyclostome 2 & - & 2.02 & 1.72 & 4.75 & 0.89 \\
\hline & Celleporella antarctica & - & 0.65 & 0.30 & 4.18 & 0.67 \\
\hline & Coralline algae & - & 1.95 & 0.00 & 3.76 & 0.76 \\
\hline & Micropora notialis & $\bullet$ & 1.09 & 0.48 & 3.47 & 0.86 \\
\hline & Serpulids & & 0.32 & 4.66 & 2.88 & 0.58 \\
\hline & Cyclostome 1 & - & 0.78 & 0.36 & 2.86 & 0.70 \\
\hline & Aimulosia antarctica & & 0.14 & 0.25 & 2.31 & 0.48 \\
\hline & Arachnopusia inchoata & & 0.17 & 0.70 & 2.04 & 0.63 \\
\hline \multicolumn{7}{|c|}{ South Cove } \\
\hline \multirow[t]{8}{*}{$8 \mathrm{~m}$} & Spirorbids & & 15.47 & 59.73 & 7.94 & 1.29 \\
\hline & Celleporella antarctica & - & 10.17 & 7.97 & 6.75 & 1.15 \\
\hline & Fenestrulina rugula & & 4.63 & 6.35 & 6.37 & 1.04 \\
\hline & Cyclostome 2 & & 0.82 & 2.00 & 4.80 & 1.06 \\
\hline & Aimulosia antarctica & & 0.60 & 1.72 & 4.49 & 1.03 \\
\hline & Folliculina sp. 1 & & 0.13 & 5.13 & 3.88 & 0.64 \\
\hline & Ellisina antarctica & & 0.15 & 0.82 & 3.64 & 0.92 \\
\hline & Cyclostome 1 & & 0.30 & 1.05 & 3.07 & 0.67 \\
\hline \multirow[t]{12}{*}{$20 \mathrm{~m}$} & Celleporella antarctica & - & 50.27 & 3.36 & 7.95 & 1.56 \\
\hline & Coralline algae & - & 7.67 & 0.00 & 6.67 & 1.36 \\
\hline & Spirorbids & $\bullet$ & 19.00 & 17.05 & 5.09 & 1.22 \\
\hline & Fenestrulina rugula & & 3.77 & 5.02 & 4.51 & 1.01 \\
\hline & Cyclostome 1 & $\bullet$ & 5.61 & 4.62 & 4.21 & 1.10 \\
\hline & Aimulosia antarctica & & 1.24 & 2.42 & 4.03 & 1.11 \\
\hline & Hydroids & $\bullet$ & 0.89 & 0.03 & 2.44 & 0.79 \\
\hline & Cyclostome 2 & & 0.42 & 0.44 & 2.40 & 0.76 \\
\hline & Serpulids & & 0.41 & 1.42 & 2.35 & 0.63 \\
\hline & Ascidian 1 & & 0.05 & 1.20 & 2.10 & 0.67 \\
\hline & Folliculina sp. 1 & & 0.21 & 0.73 & 1.98 & 0.62 \\
\hline & Chaperiopsis protecta & & 0.05 & 0.53 & 1.91 & 0.71 \\
\hline \multicolumn{7}{|c|}{ Anchorage } \\
\hline \multirow[t]{8}{*}{$8 \mathrm{~m}$} & Spirorbids & & 37.72 & 64.07 & 9.93 & 1.37 \\
\hline & Fenestrulina rugula & & 5.83 & 12.56 & 7.86 & 1.01 \\
\hline & Celleporella antarctica & $\bullet$ & 5.15 & 1.48 & 6.58 & 1.22 \\
\hline & Aimulosia antarctica & & 0.92 & 1.35 & 5.05 & 1.06 \\
\hline & Cyclostome 1 & & 0.72 & 1.06 & 4.58 & 0.99 \\
\hline & Coralline algae & $\bullet$ & 1.43 & 0.00 & 3.99 & 0.72 \\
\hline & Ellisina antarctica & & 0.34 & 0.46 & 3.09 & 0.74 \\
\hline & Ascidian 5 & & 0.06 & 0.30 & 2.21 & 0.59 \\
\hline $20 \mathrm{~m}$ & Coralline algae & $\bullet$ & 11.89 & 0.00 & 6.23 & 1.59 \\
\hline & Spirorbids & - & 70.74 & 9.48 & 5.52 & 1.33 \\
\hline & Celleporella antarctica & $\bullet$ & 20.74 & 1.46 & 4.98 & 1.48 \\
\hline & Cyclostome 1 & - & 17.13 & 4.20 & 3.93 & 1.13 \\
\hline & Foraminiferans & - & 1.93 & 0.02 & 3.34 & 1.18 \\
\hline & Ellisina antarctica & $\bullet$ & 2.87 & 2.04 & 3.09 & 1.08 \\
\hline & Fenestrulina rugula & $\bullet$ & 2.67 & 1.04 & 2.84 & 0.98 \\
\hline & Aimulosia antarctica & - & 2.74 & 1.37 & 2.57 & 0.97 \\
\hline & Hydroids & $\bullet$ & 2.76 & 0.00 & 2.42 & 0.73 \\
\hline & Ascidian 1 & & 0.13 & 1.06 & 2.20 & 0.85 \\
\hline & Camptoplites bicornis & $\bullet$ & 1.46 & 0.24 & 2.20 & 0.84 \\
\hline & Serpulids & $\bullet$ & 0.72 & 0.44 & 1.70 & 0.59 \\
\hline & Osthimosia sp. & $\bullet$ & 0.81 & 0.50 & 1.65 & 0.74 \\
\hline & Folliculina sp. 1 & - & 1.43 & 0.70 & 1.53 & 0.54 \\
\hline & Ascidian 5 & & 0.31 & 0.48 & 1.44 & 0.65 \\
\hline
\end{tabular}

Table 3. SIMPER analysis of the taxa contributing most (90\% cut-off) to dissimilarity between assemblages recruiting to upper and lower surfaces of settlement plates $\left(150 \mathrm{~cm}^{2}\right)$ at 8 and $20 \mathrm{~m}$ depth. Data are means from 6 plates over 11 (Hangar Cove and South Cove) or 9 (Anchorage) monthly sampling points from April 2002 to February 2003. Dissimilarity/SD is a relative measure of how consistent each taxon's contribution to overall dissimilarity is across all samples. Taxa recruiting predominantly to upper surfaces are indicated $(\bullet)$. Abundances are given as untransformed values but in order to downweight the influence of more abundant taxa, data were fourth-roottransformed for analysis of relative contributions to dissimilarity

Further theoretical advantages of winter settlement may be gained in terms of body size, and a trend towards winter settlement may be indicative of adaptations related to optimising growth. Firstly, post-settlement winter growth fuelled by nanophytoplankton production may afford a partial size refuge from predation and disturbance at the onset of summer. This is particularly relevant for modular organisms which can tolerate substantial colony loss once beyond the ancestrula stage (Greene et al. 1983, Barnes \& Arnold 2001a), but the attainment of a size threshold has also been shown to be critical to the survival of solitary ascidians in some environments (Osman \& Whitlatch 1998). Secondly, as the utilisable size range of food particles increases with body size in the early development of taxa such as ascidians, post-settlement growth in winter, using the available nanoplankton fraction, may allow them to attain a size at which they are able to make more efficient use of the larger phytoplankton elements which bloom in summer (Clarke \& Leakey 1996) and thus achieve optimal growth rates through their first year. Thirdly, weakly competitive, ephemeral species may reach reproductive maturity earlier as a consequence of winter settlement and thus be able to release larvae before being overgrown by superior 


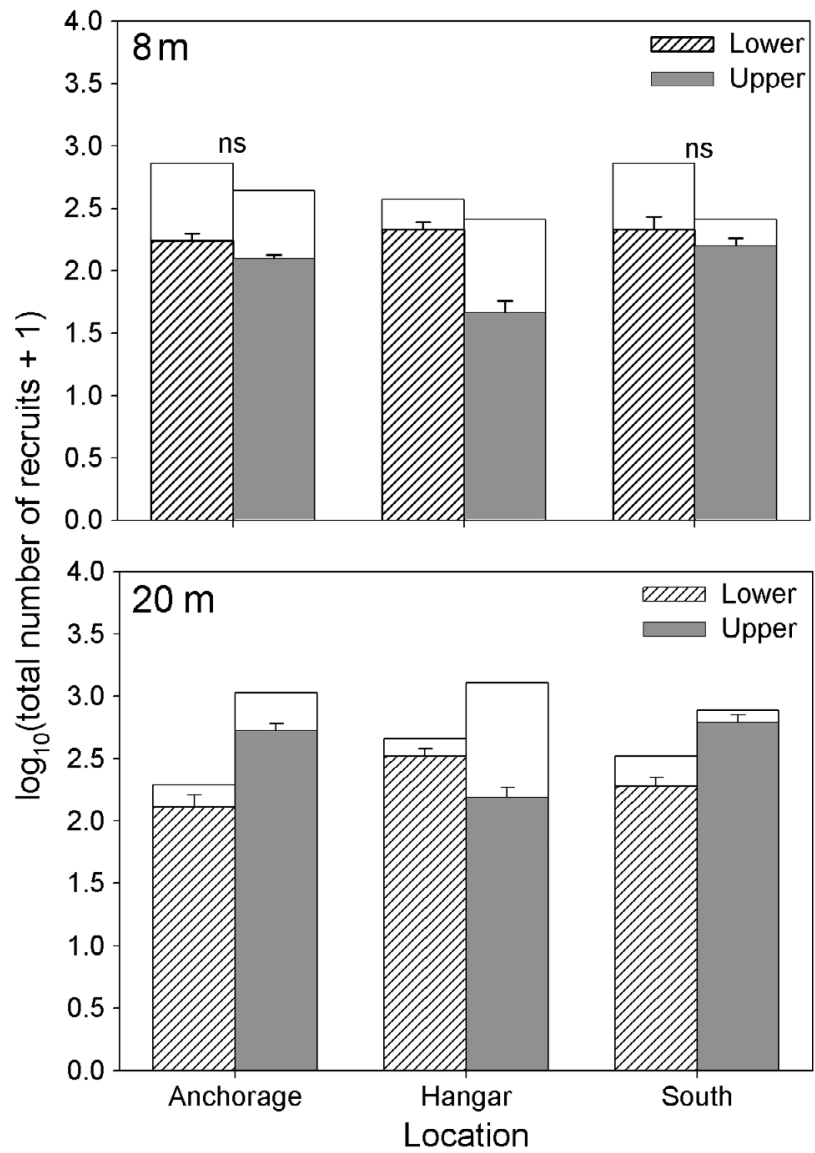

Fig. 7. Total numbers of recruits $\left(\log _{10}(N+1)\right)$ recorded on upper and lower surfaces of artificial panels at 2 depths (8 and $20 \mathrm{~m}$ ). Full height columns represent recruitment of all sessile fauna. Lower bars in each column represent recruitment excluding spirorbid polychaetes: formal comparisons are based on these values. Values plotted are means of summed recruitment per plate surface over the period March 2002 to February 2003 excluding April and November, ns indicates non-significant differences (ANOVA, $p>0.05$ ) for comparisons excluding spirorbids ( $\mathrm{n}=6$, error bars are $1 \mathrm{SE}$ ). Error bars for full height columns are omitted for clarity but are $<0.15$ in all cases

competitors during the summer. If this were the case we might predict a sequence of recruitment periods in which there is a progression from poorer to stronger overgrowth competitors from mid-winter through to late summer. The recruitment patterns of cheilostome bryozoans observed at a local scale here (Fig. 6) broadly support this prediction: weaker overgrowth competitors recruiting earlier than stronger competitors. It has previously been suggested that differences in recruitment period may be significant in the persistence of competitively inferior clades over evolutionary timescales (Barnes 2002) but, to my knowledge, a correlation between recruitment timing and competitive ability at species level has not been demonstrated before.
Many sublittoral colonisation studies have concentrated on recruitment to plate undersurfaces (e.g. Hurlbut 1991a,b, Turner \& Todd 1993, Osman \& Whitlatch 1995, Stanwell-Smith \& Barnes 1997) with few making comparisons between colonisation of upper and lower surfaces (e.g. Nandakumar 1995, Babcock \& Mundy 1996, Barnes 1996). The results of the present study, however, show recruitment to upper surfaces which is comparable to, and at times exceeds, that on lower surfaces. This suggests that the observed distributions of established sessile assemblages in this region, in which the protected undersurfaces and overhangs of hard substrata are generally more heavily colonised than are exposed upper surfaces (Barnes 1995, Bowden 2005), are the result of post-settlement processes.

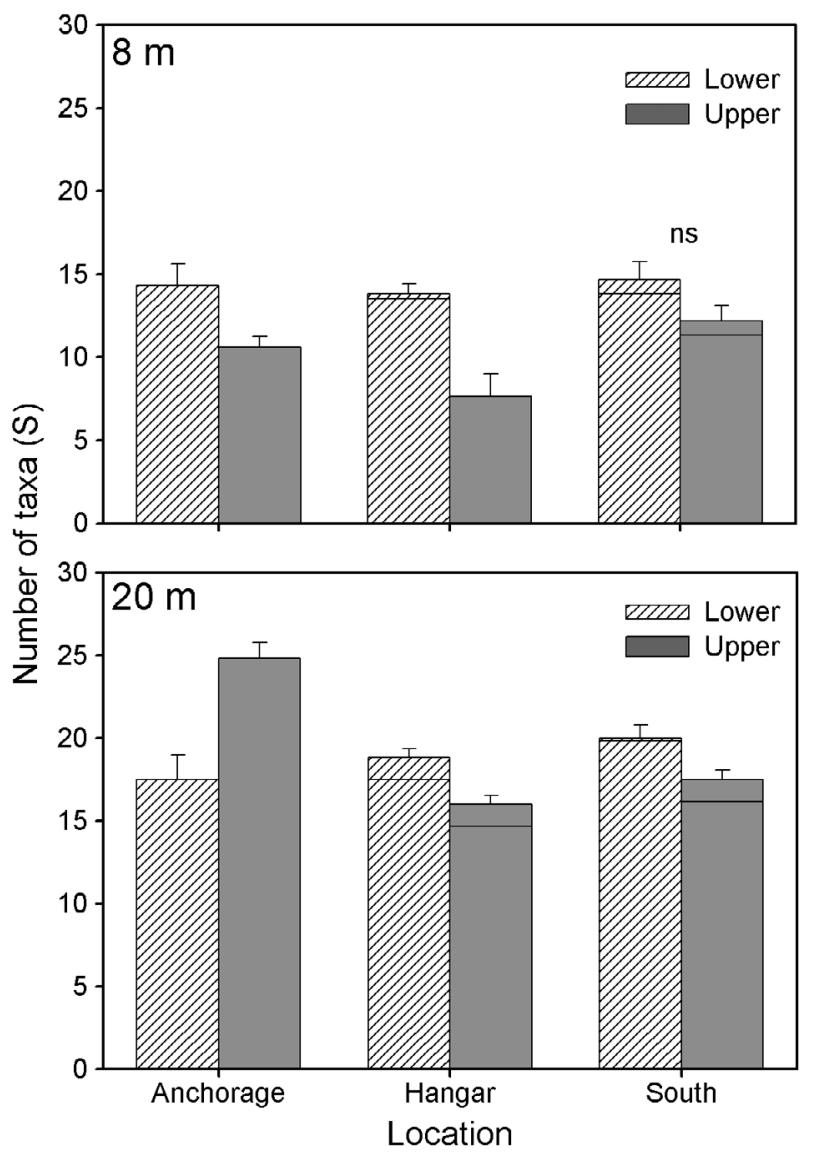

Fig. 8. Total numbers of taxa recorded on upper and lower surfaces of artificial panels at 2 depths ( 8 and $20 \mathrm{~m}$ ) over the period March 2002 to February 2003. Crossbars on Hangar and South plots indicate mean total number of taxa excluding data from April and November 2003 to show comparisons with Anchorage, for which there are no data in these months. Error bars on these values are omitted for clarity but are $<1.4$ in all cases. ns indicates non-significant differences (ANOVA $p>0.05) . n=6$, error bars are 1 SE. Full data are used for formal comparisons between plate surfaces 
The larvae of many benthic species exhibit settlement preferences in response to a variety of environmental cues (e.g. Keough \& Downes 1982, Durante 1991, Hurlbut 1993, Rodriguez et al. 1993, McKinney \& McKinney 2002, Baird et al. 2003). If larval selection of settlement surface were the principal mechanism controlling distributions in the present study, however, we would not expect to see the significant changes in the ratio of recruitment to upper and lower surfaces observed between seasons (Fig. 4), and particularly not the seasonal variation observed within individual species such as Fenestrulina rugula (Fig. 9). For these species, if we assume that settlement (i.e. the total number of settling larvae) continues to be evenly distributed between upper and lower plate surfaces during the summer months (November to February), as appears to be the case from August to October, the pattern of reduced recruitment to upper surfaces during the summer period suggests that there is increased mortality of recruits on upper surfaces during this period. Other
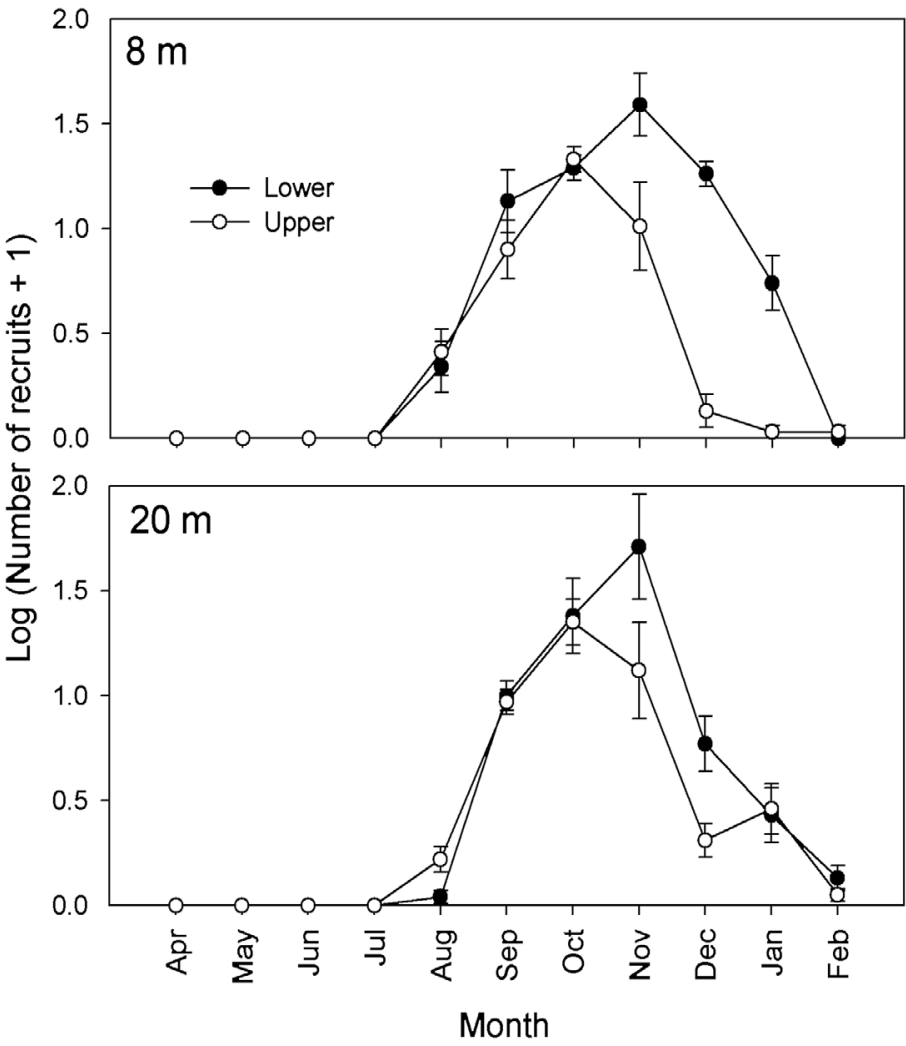

Fig. 9. Fenestrulina rugula. Recruitment to upper and lower surfaces of settlement plates at 2 depths in South Cove, illustrating the difference in numbers of recruits to upper and lower surfaces from November to January at $8 \mathrm{~m}$, and from November to December at $20 \mathrm{~m}$. In these months there were significantly fewer recruits recorded on upper than lower surfaces at both depths (ANOVA, $\mathrm{p}<0.05$ in all cases). $\mathrm{n}=6$, error bars are $1 \mathrm{SE}$

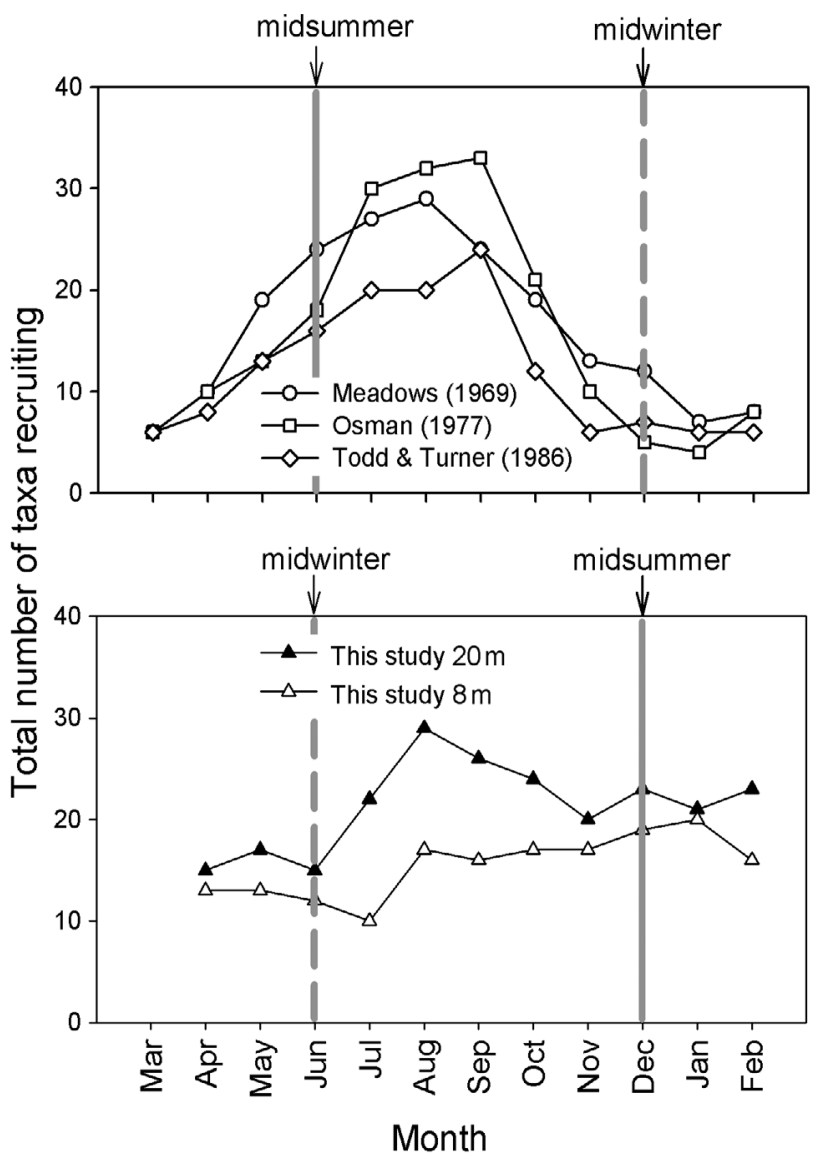

Fig. 10. Comparison of the total numbers of sessile faunal taxa recruiting per month to artificial plates in 3 northern hemisphere temperate sublittoral studies (top) and in the present study (bottom). The months of mid-winter and midsummer are indicated, contrasting the post mid-summer peak of recruitment in the temperate latitude studies with a post midwinter peak at $20 \mathrm{~m}$ in this study. Values plotted are totals per month in each study. Depths in the temperate studies range from 1 to $3 \mathrm{~m}$ below mean low water

explanations for this pattern might include a change in larval settling behaviour caused by increasing light levels during the onset of summer. However, the apparently abrupt decrease in recruitment to upper surfaces in November, rather than a more gradual tailing-off matched to changes in light intensity, argues against this.

Descriptions of non-random distributions resulting from differential post-settlement mortality from predation, grazing, or biotic disturbance are common in the literature (reviewed in Gosselin \& Qian 1997, Hunt \& Scheibling 1997). From the evidence in such studies of the effects of grazing by urchins and gastropods, and given the high densities of the urchin Sterechinus neumayeri and the limpet Nacella concinna in the study area (Bowden 2005) and observed grazing on the plates during this study, it seems reasonable to hypoth- 
esise that these taxa are responsible for considerable mortality of settling larvae and juveniles on exposed surfaces. Furthermore, Brockington et al. (2001) have shown that $S$. neumayeri is largely inactive during the austral winter but resumes feeding during November, and winter reduction of feeding has also been observed in N. concinna (Fraser et al. 2002, A. Clarke unpubl. data). The correlation of these observations with the decline in upper-surface recruitment observed in November here (Fig. 9) lends weight to the hypothesis that grazing by these species is reponsible for significant mortality of settling larvae and juveniles of sessile taxa.

In terms of the major taxonomic groups recorded and their relative abundances, the results presented here have many similarities with sessile assemblages recorded in other latitudes (e.g. Greene et al. 1983, Winston \& Jackson 1984, Todd \& Turner 1986, Holmes et al. 1997, Smith \& Witman 1999). The numerical dominance of recruitment by calcareous polychaetes and bryozoans is typical of both temperate and tropical fouling assemblages, as are the high diversity of cheilostome bryozoans and the annual cycles of recruitment suggested here. The effects of benthic grazers and predators on observed distributions are also common to sessile assemblages in other latitudes. However, although world-wide there are still few comparable studies of whole-assemblage recruitment at monthly resolution, the feature which most distinguishes the present data from temperate recruitment patterns is the apparent trend for greater numbers of species to recruit during winter. The significance of this trend in terms of life-cycle adaptations to environmental conditions prevailing in the Antarctic over evolutionary time is open to conjecture and, as the present data span only $1 \mathrm{yr}$, there is clearly a need for longerterm studies to determine the generality of the pattern. It is possible, however, that the life-histories of such species represent adaptation to an environment in which 2 major agents of disturbance, ice-impact and biological disturbance, peak in the same season as does the availability of food, and thus select for a pattern of winter recruitment. Such a hypothesis is difficult to test, but a comparison of the recruitment timings of endemic and non-endemic Antarctic species with overlapping ranges would be a practicable undertaking and would be predicted to show a higher incidence of winter recruitment among endemic species.

Acknowledgements. I thank A. Clarke, L. S. Peck, and D. K. A. Barnes for valuable critical input throughout the project, together with all in the marine team at Rothera from 2000 to 2003, particularly P. Horne and R. Piper for diving support. The manuscript was improved following suggestions from P. Dayton and 5 anonymous reviewers. This study forms part of the LATEST research programme of the British Antarctic Survey.

\section{LITERATURE CITED}

Arntz WE, Brey T, Gallardo VA (1994) Antarctic zoobenthos. Oceanogr Mar Biol 32:241-304

Babcock R, Mundy C (1996) Coral recruitment: consequences of settlement choice for early growth and survivorship in two scleractinians. J Exp Mar Biol Ecol 206:179-201

Baird AH, Babcock RC, Mundy CP (2003) Habitat selection by larvae influences the depth distribution of six common coral species. Mar Ecol Prog Ser 252:289-293

Barnes DKA (1995) Sublittoral epifaunal communities at Signy Island, Antarctica. 2. Below the ice-foot zone. Mar Biol 121:565-572

Barnes DKA (1996) Low levels of colonisation in Antarctica: the role of bryozoans in early community development. In: Gordon DP, Smith AM, Grant-Mackie JA (eds) Bryozoans in space and time. Proceedings of the 10th International Bryozoology Conference. National Institute of Water \& Atmospheric Research, Wellington, p 19-28

Barnes DKA (1999) The influence of ice on polar nearshore benthos. J Mar Biol Assoc UK 79:401-407

Barnes DKA (2002) Clade perseverance from mesozoic to present: a multidisciplinary approach to interpretation of pattern and process. Biol Bull 203:161-172

Barnes DKA, Arnold R (2001a) Competition, sublethal mortality and diversity on Southern Ocean coastal rock communities. Polar Biol 24:447-454

Barnes DKA, Arnold R (2001b) A growth cline in encrusting benthos along a latitudinal gradient within Antarctic waters. Mar Ecol Prog Ser 210:85-91

Barnes DKA, Brockington S (2003) Zoobenthic biodiversity, biomass and abundance at Adelaide Island, Antarctica. Mar Ecol Prog Ser 249:145-155

Barnes DKA, Clarke A (1995) Seasonality of feeding-activity in antarctic suspension feeders. Polar Biol 15:335-340

Barnes DKA, Rothery P (1996) Competition in encrusting Antarctic bryozoan assemblages: outcomes, influences and implications. J Exp Mar Biol Ecol 196:267-284

Bingham BL, Walters LJ (1989) Solitary ascidians as predators of invertebrate larvae-evidence from gut analyses and plankton samples. J Exp Mar Biol Ecol 131:147-159

Booth DJ, Brosnan DM (1995) The role of recruitment dynamics in rocky shore and coral reef fish comminities. Adv Ecol Res 26:309-383

Bosch I, Rivkin RB (1988) Feeding dynamics by planktotrophic asteroid larvae in oligotrophic environments. Am Zool 28:A167-A167

Bowden DA (2005) Quantitative characterisation of of shallow marine benthic assemblages at Ryder Bay, Adelaide Island, Antarctica. Mar Biol 146:1235-1249

Brey T, Clarke A (1993) Population-dynamics of marine benthic invertebrates in antarctic and sub-antarctic environments-are there unique adaptations. Antarct Sci 5: 253-266

Brockington S (2001) The seasonal energetics of the Antarctic bivalve Laternula elliptica (King and Broderip) at Rothera Point, Adelaide Island. Polar Biol 24:523-530

Brockington S, Clarke A (2001) The relative influence of temperature and food on the metabolism of a marine invertebrate. J Exp Mar Biol Ecol 258:87-99

Brockington S, Clarke A, Chapman ALG (2001) Seasonality of feeding and nutritional status during the austral winter in the Antarctic sea urchin Sterechinus neumayeri. Mar Biol 139:127-138

Brown KM, Fraser KP, Barnes DK, Peck LS (2004) Links between the structure of an Antarctic shallow-water community and ice-scour frequency. Oecologia 141:121-129 
Caley MJ, Carr MH, Hixon MA, Hughes TP, Jones GP, Menge BA (1996) Recruitment and the local dynamics of open marine populations. Annu Rev Ecol Syst 27:477-500

Clarke A, Johnston NM (2003) Antarctic marine benthic diversity. Oceanogr Mar Biol 41:47-114

Clarke A, Leakey RJG (1996) The seasonal cycle of phytoplankton, macronutrients, and the microbial community in a nearshore Antarctic marine ecosystem. Limnol Oceanogr 41:1281-1294

Clarke KR, Warwick RM (2001) Change in marine communities: an approach to statistical analysis, PRIMER-E, Plymouth

Connell JH (1985) The consequences of variation in initial settlement vs postsettlement mortality in rocky intertidal communities. J Exp Mar Biol Ecol 93:11-45

Connolly SR, Roughgarden J (1999) Theory of marine communities: competition, predation, and recruitmentdependent interaction strength. Ecol Monogr 69:277-296

Connolly SR, Menge BA, Roughgarden J (2001) A latitudinal gradient in recruitment of intertidal invertebrates in the northeast Pacific Ocean. Ecology 82:1799-1813

Dayton PK (1989) Interdecadal variation in an Antarctic sponge and its predators from oceanographic climate shifts. Science 245:1484-1486

Dayton PK (1990) Polar benthos. In: Smith WO (ed) Polar oceanography. Academic Press, London, p 631-685

Durante KM (1991) Larval behavior, settlement preference, and induction of metamorphosis in the temperate solitary ascidian Molgula citrina Alder and Hancock. J Exp Mar Biol Ecol 145:175-187

Fraser KPP, Clarke A, Peck LS (2002) Feast and famine in Antarctica: seasonal physiology in the limpet Nacella concinna. Mar Ecol Prog Ser 242:169-177

Gaines SD, Bertness MD (1992) Dispersal of juveniles and variable recruitment in sessile marine species. Nature 360: $579-580$

Gaines SD, Bertness M (1993) The dynamics of juvenile dispersal-why field ecologists must integrate. Ecology 74 : $2430-2435$

Gimenez L (2004) Marine community ecology: importance of trait-mediated effects propagating through complex life cycles. Mar Ecol Prog Ser 283:303-310

Gosselin LA, Qian PY (1997) Juvenile mortality in benthic marine invertebrates. Mar Ecol Prog Ser 146:265-282

Greene CH, Schoener A, Corets E (1983) Succession on marine hard substrata - the adaptive significance of solitary and colonial strategies in temperate fouling communities. Mar Ecol Prog Ser 13:121-129

Gutt J (2001) On the direct impact of ice on marine benthic communities, a review. Polar Biol 24:553-564

Gutt J, Starmans A, Dieckmann G (1996) Impact of iceberg scouring on polar benthic habitats. Mar Ecol Prog Ser 137: 311-316

Harder T, Lam C, Qian PY (2002) Induction of larval settlement in the polychaete Hydroides elegans by marine biofilms: an investigation of monospecific diatom films as settlement cues. Mar Ecol Prog Ser 229:105-112

Hayward PJ (1995) Antarctic cheilostomatous bryozoa. Oxford University Press, Oxford

Holmes NJ, Harriott VJ, Banks SA (1997) Latitudinal variation in patterns of colonisation of cryptic calcareous marine organisms. Mar Ecol Prog Ser 155:103-113

Hunt HL, Scheibling RE (1997) Role of early post-settlement mortality in recruitment of benthic marine-invertebrates. Mar Ecol Prog Ser 155:269-301

Hurlbut CJ (1991a) Community recruitment-settlement and juvenile survival of 7 cooccurring species of sessile marine invertebrates. Mar Biol 109:507-515

Hurlbut CJ (1991b) Larval substratum selection and postsettlement mortality as determinants of the distribution of 2 bryozoans. J Exp Mar Biol Ecol 147:103-119

Hurlbut CJ (1993) The adaptive value of larval behavior of a colonial ascidian. Mar Biol 115:253-262

Keough MJ, Downes BJ (1982) Recruitment of marine-invertebrates - the role of active larval choices and early mortality. Oecologia 54:348-352

Kirkwood JM, Burton HR (1988) Macrobenthic species assemblages in Ellis Fjord, Vestfold Hills, Antarctica. Mar Biol 97:445-457

Kowalke J (1999) Filtration in antarctic ascidians — striking a balance. J Exp Mar Biol Ecol 242:233-244

McKinney FK, McKinney MJ (2002) Contrasting marine larval settlement patterns imply habitat-seeking behaviours in a fouling and a cryptic species (phylum Bryozoa). J Nat Hist 36:487-500

Meadows PS (1969) Sublittoral fouling communities on Northern coasts of Britain. Hydrobiologia 34:273-294

Menge BA (1991) Relative importance of recruitment and other causes of variation in rocky intertidal community structure. J Exp Mar Biol Ecol 146:69-100

Menge BA (2000) Recruitment vs. postrecruitment processes as determinants of barnacle population abundance. Ecol Monogr 70:265-288

Nandakumar K (1995) Competitive interactions among sessile organisms in Tomioka Bay, south Japan: importance of light conditions on the panel surface. Mar Biol 121:713-719

Osman RW (1977) The establishment and development of a marine epifaunal community. Ecol Monogr 47:37-63

Osman RW, Whitlatch RB (1995) The influence of resident adults on recruitment-a comparison to settlement. J Exp Mar Biol Ecol 190:169-198

Osman RW, Whitlatch RB (1998) Local control of recruitment in an epifaunal community and the consequences to colonization processes. Hydrobiologia 376:113-123

Pearse JS, Bosch I, Pearse VB, Basch LV (1991a) Bacterivory by Bipinnarias - in the Antarctic but not in California. Am Zool 31:A6-A6

Pearse JS, McClintock JB, Bosch I (1991b) Reproduction of Antarctic benthic marine-invertebrates-tempos, modes, and timing. Am Zool 31:65-80

Pearse VB, Pearse JS (1991) Year-long settlement plate study yields no antarctic placozoans, and surprisingly little else. Antarct J US:149-150

Peck LS, Brockington S, Vanhove S, Beghyn M (1999) Community recovery following catastrophic iceberg impacts in a soft-sediment shallow-water site at Signy Island, Antarctica. Mar Ecol Prog Ser 186:1-8

Porter KG, Feig YG (1980) The use of DAPI for identifying and counting aquatic micoflora. Limnol Oceanogr 25:943-948

Quinn GP, Keough MJ (2002) Experimental design and data analysis for biologists. Cambridge University Press, Cambridge

Randlov A, Riisgard HU (1979) Efficiecy of particle retention and filtration rate in four species of ascidians. Mar Ecol Prog Ser 1:55-59

Rauschert M (1991) Ergebnisse der faunistischen Arbeiten im Benthal von King George Island (Südshetlandinseln, Antarktis). Ber Pol Meeres 76

Rivkin RB, Bosch I, Pearse JS, Lessard EJ (1986) Bacterivory - a novel feeding mode for asteroid larvae. Science 233: 1311-1314

Rodriguez SR, Ojeda FP, Inestrosa NC (1993) Settlement of benthic marine-invertebrates. Mar Ecol Prog Ser 97: 193-207 
Sahade R, Tatian M, Esnal GB (2004) Reproductive ecology of the ascidian Cnemidocarpa verrucosa at Potter Cove, South Shetland Islands, Antarctica. Mar Ecol Prog Ser 272: 131-140

Smith F, Witman JD (1999) Species diversity in subtidal landscapes: maintenance by physical processes and larval recruitment. Ecology 80:51-69

Somerfield PJ, Clarke KR, Olsgard F (2002) A comparison of the power of categorical and correlational tests applied to community ecology data from gradient studies. J Anim Ecol 71:581-593

Stanwell-Smith D, Barnes DKA (1997) Benthic community development in Antarctica: recruitment and growth on settlement panels at Signy Island. J Exp Mar Biol Ecol 212: 61-79

Todd CD (1998) Larval supply and recruitment of benthic invertebrates: do larvae always disperse as much as we believe? Hydrobiologia 376:1-21

Todd CD, Keough MJ (1994) Larval settlement in hard substratum epifaunal assemblages: a manipulative field study of the effects of substratum filming and the presence of incumbents. J Exp Mar Biol Ecol 181:159-187

Todd CD, Turner SJ (1986) Ecology of intertidal and sub-

Editorial responsibility: Otto Kinne (Editor-in-Chief),

Oldendorf/Luhe, Germany littoral cryptic epifaunal assemblages. 1. Experimental rationale and the analysis of larval settlement. J Exp Mar Biol Ecol 99:199-231

Turner SJ, Todd CD (1993) The early development of epifaunal assemblages on artificial substrata at 2 intertidal sites on an exposed rocky shore in St Andrews Bay, NE Scotland. J Exp Mar Biol Ecol 166:251-272

Underwood AJ, Anderson MJ (1994) Seasonal and temporal aspects of recruitment and succession in an intertidal estuarine fouling assemblage. J Mar Biol Assoc UK 74: 563-584

Underwood AJ, Fairweather PG (1989) Supply-side ecology and benthic marine assemblages. Trends Ecol Evol 4: $16-20$

Vaughan DG, Marshall GJ, Connolley WM, Parkinson C and 5 others (2003) Recent rapid regional climate warming on the Antarctic Peninsula. Clim Change 60:243-274

Winston JE, Jackson JBC (1984) Ecology of cryptic coral-reef communities. 4. Community-development and life histories of encrusting cheilostome bryozoa. J Exp Mar Biol Ecol 76:1-21

Young CM (2002) Atlas of marine invertebrate larvae. Academic Press, San Diego, CA

Submitted: September 20, 2004; Accepted: March 17, 2005

Proofs received from author(s): July 19, 2005 